\title{
THE IMPACT OF BRIBERY ON FIRM PERFORMANCE: EVIDENCE FROM CENTRAL AND EASTERN EUROPEAN COUNTRIES
}

\section{Anna Kochanova}
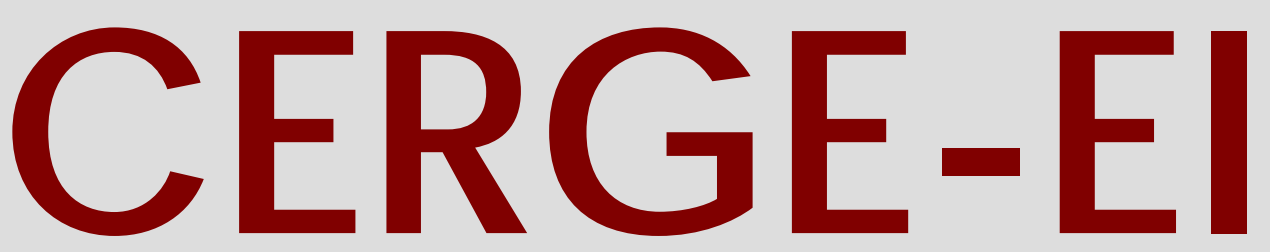

Charles University Centerfor Ec onomic Research and Graduate Education Academy of Sciences of the Czech Republic Ec onomic s Institute 


\title{
Working Paper Series 473 (ISSN 1211-3298)
}

\section{The Impact of Bribery on Firm Performance: Evidence from Central and Eastern European Countries}

\author{
Anna Kochanova
}

CERGE-EI

Prague, December 2012 
ISBN 978-80-7343-277-5 (Univerzita Karlova. Centrum pro ekonomický výzkum a doktorské studium)

ISBN 978-80-7344-269-9 (Národohospodářský ústav AV ČR, v.v.i.) 


\title{
The Impact of Bribery on Firm Performance: Evidence from Central and Eastern European Countries
}

\author{
Anna Kochanoved \\ CERGE-EI
}

\begin{abstract}
I examine the relation between bureaucratic corruption ('to get things done') and firm performance in Central and Eastern European countries. While previous research relies on data from the BEEPS survey, which suffers from excessive nonreporting of corporate performance, I combine the information on bribery practices from the BEEPS with reliable firm performance data from the Amadeus database. The estimates, identified from within-firm variation, suggest that bureaucratic corruption negatively affects both the sales and labor productivity growth of firms. However, conditional on a given level of bribery in a narrowly defined local market, a higher dispersion of firms' bribing behavior within such a market appears to facilitate firm performance. I provide an explanation for this finding and also investigate the effect of bribery with respect to the heterogeneity of firms in terms of their size, inclusion in the manufacturing or service sector, stability, and countries' overall institutional environments.
\end{abstract}

KEYWORDs: Bureaucratic corruption; Firms' bribing behavior; Firm performance; CEE countries.

JEL Classifications: D22; D73; O12; P37.

\footnotetext{
*ACKnowledgements: I am grateful to Jan Hanousek for helpful comments, guidance and support. I thank also Alena Bicakova, Marina Dodlova, Randy Filer, Vahagn Jerbashian, Stepan Jurajda, Evzen Kocenda and Patrick Warren for valuable comments, and Laura Strakova for editing. The earlier draft of this paper benefited from comments from participants at the Economic Governance and Innovation Conference 2011, ESNIE 2012 and BOFIT Research Seminar. The financial support of GDN grant No. RRC 11-004 and the Czech Science Foundation project No. P402/12/G097 DYME Dynamic Models in Economics are acknowledged. All errors remaining in this text are the responsibility of the author.

${ }^{\dagger}$ Contact: CERGE-EI, Politickych veznu 7, Prague, 110 00, Czech Republic. Tel.: (+420) 224005 123; E-mail: anna.kochanova@cerge-ei.cz.

${ }^{\ddagger}$ CERGE-EI is a joint workplace of the Center for Economic Research and Graduate Education, Charles University in Prague, and the Economic Institute of Academy of Sciences of the Czech Republic.
} 


\begin{abstract}
Abstrakt
Zkoumám vztah mezi byrokratickou korupcí ('aby se věci pohnuly') a výkonností firem v zemích střední a východní Evropy. Zatímco předchozí výzkum je založen na datech z výzkumu BEEPS, který trpí nadměrným nereportováním korporátních výsledků, já kombinuji informace o uplácení z BEEPS se spolehlivými daty o výsledcích firem z databáze Amadeus. Odhady, identifikované z variace uvnitř firmy, naznačují, že byrokratická korupce negativně ovlivňuje jak tržby tak růst produktivity práce firem. Na druhou stranu v závislosti na dané úrovni uplácení v úzce definovaném místním trhu se ale vyšší disperze úplatného chování firem uvnitř takového trhu zdá usnadňovat činnost firem. Přináším vysvětlení pro toto zjištění a také zkoumám efekt uplácení ve vztahu k heterogenitě firem co do velikosti, začlenění do výrobního nebo služebního odvětví ekonomiky, stability, a celkového institučního prostředí zemí.
\end{abstract}




\section{Introduction}

In countries with weak policies and legal systems, corruption is considered a strong and painful constraint to their economic functioning, growth, and development. It is a central and problematic topic for the governments of these countries and for international organizations (such as the World Bank, the IMF, the UN or the OECD), whose job it is to uncover the source of this disease and help overcome it (Kaufmann, 2005; Khan, 2006).

This study contributes to the ongoing debate about two opposing consequences of corruption on economic performance and to some extent attempts to reconcile them. One strand of the literature considers corruption a "grease the wheels" instrument that helps overcome cumbersome bureaucratic constraints, inefficient public services, and rigid laws (Leff, 1964; Huntington, 1968; Lui, 1985; Lein, 1986), especially when countries' institutions are weak, and ill functioning (Acemoglu and Verdier, 2000; Meon and Weill, 2010; De Vaal and Ebben, 2011). Another strand argues that corruption curbs economic performance owing to rent seeking, increase of transaction costs and uncertainty, inefficient investments, and misallocation of production factors (Murphy et al., 1991; Shleifer and Vishny, 1993; RoseAckerman, 1997; Kaufmann and Wei, 2000).

A vast amount of empirical evidence from cross-country analysis generally confirms that corruption harms investments, economic growth, and development (Mauro, 1995; Svensson, 2005; Campos et al., 2010). In these papers corruption reflects public and manager perceptions of both bureaucratic and grand corruption in a country $\left.\right|^{12}$ Empirical firm-level research, in turn, utilizes measures of bureaucratic corruption (bribery) such as the amount of bribes paid or the frequency of paying bribes to public officials to 'get things done'. This research mostly finds a negative or insignificant relation between bribery and firm performance (Gaviria, 2002; McArthur and Teal, 2004; Fisman and Svensson, 2007; De Rosa et al., 2010). Only a few papers, such as Vial and Hanoteau's (2010) plant-level study for Indonesia, report a positive relation. To date, however, firm-level research has remained scarce due to the lack of available data and limited capacity to address the endogeneity of bribery measures.

In this paper I aim to fill a gap in firm-level empirical research on bureaucratic corruption by overcoming data and methodological shortcomings of previous literature. I study the impact of bribery, measured as the frequency of making extra unofficial payments to public officials to 'get things done', on the real sales and labor

\footnotetext{
${ }^{1}$ See, for example, Jain (2001) for a discussion of different forms of corruption.

${ }^{2}$ Most commonly used measures are the Control of Corruption indicator produced by the World Bank and the Corruption Perception Index published by the Transparency International.
} 
productivity growth of firms in Central and Eastern European (CEE) countries. In addition, I investigate this impact with respect to the heterogeneity of firms in terms of their size, inclusion in the manufacturing or service sector, stability, and countries' overall institutional environments. Existing research has had limited opportunities to explore this direction.

Information on firm-level bribery practices usually comes from anonymous surveys, in which firms may be reluctant to reveal their financial information. In the often used BEEPS or WBES databases $\mathrm{S}^{3} 40-50 \%$ of firms thus do not report their performance. Responses to the survey questions are generally also subject to managers' pessimism or optimism. These features likely cause erroneous inference from the data. Further, due to sampling requirements and limited ability to follow firms over time, existing studies mostly deal with cross-sectional data, an invitation for endogeneity problems.

To overcome these data shortcomings, I combine reliable and large firm-level data (more than 500,000 firms) on balance sheets and profit/loss account items from the Amadeus database with firm-level data on bribery practices from the BEEPS. In the new dataset (hereafter, the BEEPS-Amadeus dataset) the bribing behavior of individual firms is unobserved, because it is impossible to exactly match firms from the two databases. Instead, I compute the averages and standard deviations of the bribery measure for country - survey wave - industry (2 digit ISIC code) - firm size (micro, small and large) - location size (capital, city with population over 1 mil and below 1 mil) cells using the BEEPS and assign them to every individual firm from Amadeus belonging to the same cell. These two statistics fully describe the average bribery level and (un)evenness of firms' bribing behavior within cells, which I term 'local bribery environments'. It is thus important to bear in mind that I examine the impact of 'local bribery environments' in narrowly defined local markets rather than firms' actual bribing behavior on firm performance.

Handling with the average bribery measure at the cell-level is not ad hoc. It is in line with the arguments of Svensson (2003) and Fisman and Svensson (2007) that bribery is industry and region specific in a country. It is also a common way to reduce endogeneity between bribery or subjective obstacles of doing business and firm performance in papers utilizing solely the BEEPS or similar datasets given the lack of instrumental variables availability (Dollar et al., 2005; Kinda et al., 2009).

To date, I am aware of only two papers, Anos-Casero and Udomsaph (2009) and Commander and Svejnar (2011), that have attempted to combine the BEEPS and

${ }^{3}$ The BEEPS (Business Environment and Enterprise Performance Survey) is a part of the global WBES (World Bank Enterprise Survey). 
Amadeus. They analyze the effect of subjective business environment constraints on firm performance. My main departure from the approach of these papers to link the two databases is that I use less aggregate dimension of cells. In particular, I separate micro firm with fewer than 10 employees from small firms with fewer than 50 employees. This is motivated by the fact that nearly $45 \%$ of firms in the BEEPS are micro, and that they generally tend to be exempted from some bureaucratic regulations and taxes (EC, 2011).

The BEEPS-Amadeus dataset consists of large firm-level panel data for 14 CEE countries over the 1999-2007 time span. It has more accurate information on firms' economic activity and bribery $\left.\right|^{4}$ than the BEEPS alone. The panel structure and the possibility to account for firm fixed effects help mitigate the endogeneity between bribery and firm performance. The use of the two independent data sources jointly further reduces this problem.

The results of the empirical analysis, identified from-within firm variation, suggest that a higher bribery level impedes both the real sales and labor productivity growth of an average firm. This is generally consistent with the existing firm- and macro-level empirical research. The impact is more pronounced in the case of labor productivity growth, possibly because it is subject to rigid contracts with employees and can better reflect the rent-seeking behavior of firms.

Nevertheless, I find an evidence in support of the "grease the wheels" hypothesis. Conditional on a given level of bureaucratic corruption in a local environment, a higher unevenness of firms bribing behavior within such an environment appears to facilitate firm performance. Moreover, average firm performance in uneven environments seems to be higher than in close to bribe-free environments. This result implies that in more uneven local bribery environments negative externalities from bureaucratic corruption are negligible, and bribery likely helps overcome operational and growth constraints for favored firms and/or for those with stronger willingness to pay. Non-bribing firms in such environments, in turn, seem to be more efficient in production and growth, so that both types of firms generate increasing growth rates on average. The chance of receiving benefits from bribery may be one reason why corruption does not vanish in spite of its overall damaging effect. The task for policymakers, therefore, is to increase the transparency of interactions between firms and public officials and ensure the evenness of public service provision.

Further results suggest that micro firms and incumbent firms (those that are present in the sample over all years) are the least affected by bureaucratic corruption. Firms from the construction, wholesale, and retail trade sectors are able to gain

\footnotetext{
${ }^{4}$ The latter is true assuming that firm-specific perceptions and measurement error are averaged out.
} 
the most in more uneven local environments. Finally, in countries with weaker institutions, proxied by the Rule of Law indicator, the effects of bribery level and (un)evenness of firms bribing behavior are the least pronounced.

The next section describes the theoretical background and empirical evidence on the possible relation between bribery and firm performance, and introduces the notion of 'local bribery environments'. Section 3 describes the data and merging of the two databases. Section 4 outlines the empirical methodology, section 5 presents the results and robustness checks, and section 6 concludes.

\section{Links between bribery and firm performance}

\subsection{Theoretical background and some empirical evidence}

According to the "grease the wheels" hypothesis, firms can benefit from bribery if it helps to overcome bureaucratic constraints, inefficient public services, rigid or bad laws (Leff, 1964; Huntington, 1968). Using the "queue model," Lui (1985), for instance, shows that bribes can expedite obtaining public services. In line with that Beck and Maher (1986) and Lein (1986) suggest that bribing is similar to bidding in a competitive auction, which results in an efficient allocation of public services, licenses, and permits.

The "grease the wheels" hypothesis, however, has been extensively criticized. In his later work Lein (1990), for example, shows that outcomes in the "auction model" can be inefficient if there is discrimination among firms. Kaufmann and Wei (2000) argue that the "grease the wheels" hypothesis holds only when the amount of public services and time of their provision are exogenous. But in a general equilibrium framework public officials have incentives to increase the burden of bureaucracy in order to extract more bribes, thereby eliminating the possible benefits to firms. Rose-Ackerman (1997) suggests that less efficient firms, but with better connections with public officials and/or larger market power, may offer higher bribes and obtain public services faster. In the same way, incumbent firms may prevent the entrance of new firms into markets, leading to an increase in barriers to entry and undermining competition: ${ }^{5}$

Further, bribing can be too costly and undermine firms' profit (Sanyal, 2004), subsequent production, and growth. It also creates even bigger market distortions than taxation, because of the need to keep illegal transactions secret and the uncertainty of delivering public services in exchange for a bribe on time, as Shleifer and

\footnotetext{
${ }_{5}^{5}$ The present paper, however, does not directly deal with firm entry; firms therefore can benefit if bribes help to preserve or gain market power.
} 
Vishny (1993) demonstrate. Murphy et al. (1991) show that corruption forces the reallocation of talent from production to rent-seeking. As a result, firms may not be managed by the best talent, and hence expand less or be less productive. Applying the authors' arguments to the employment structure of a firm, we can also see that a higher bribery can result in a larger share of employees being occupied in nonproductive activities, namely bargaining with public officials and searching for ways to overcome bureaucratic constraints. This can undermine the labor productivity of firms.

The development of institutional economics (North, 1990) has encouraged academics to distinguish the effects of corruption and bribery in different institutional environments. Acemoglu and Verdier (2000), for instance, show that when the government intervenes to correct market failures, a certain amount of corruption may exist as part of an optimal allocation. Infante and Smirnova (2009) introduce institutions directly into the model of Acemoglu and Verdier (2000) and demonstrate that in weaker institutional environments, rent-seeking bureaucrats can help improve the productivity of entrepreneurs. Similarly, De Vaal and Ebben (2011) suggest that when the initial quality of institutions is below a certain threshold, bureaucratic corruption facilitates economic performance. In a cross-country empirical analysis Meon and Weill (2010) show that corruption helps improve aggregate efficiency especially in countries with weaker institutions.

The empirical firm-level evidence on the relationship between bureaucratic corruption and firm performance is inconclusive. Some research finds either an insignificant or negative impact of bribery on the sales growth or productivity of firms: Gaviria (2002) for Latin America, McArthur and Teal (2004) for Africa, Fisman and Svensson (2007) for Uganda. For CEE and the former Soviet Union region, De Rosa et al. (2010) find that bribery more negatively affects firm productivity in non-EU countries, and, generally, in those with weaker overall institutional environments. For empirical analysis De Rosa et al. (2010) use the last wave of the BEEPS, and the other mentioned authors use similar anonymous datasets. Vial and Hanoteau (2010), in contrast, employ a unique plant-level panel data and report a positive impact of bribery on firm growth in Indonesia during the Suharto era characterized by high corruption, cronyism, and patronage.

Both theoretical arguments and empirical evidence regarding the consequences of bribery on firm performance, thus, is ambiguous. The present study attempts to shed light on this issue and contribute to the empirical literature by utilizing an improved dataset and methodology. 


\subsection{Local bribery environments}

The institutional environment of a country largely determines its economic level of development (Acemoglu, 2003), overall corruption level and its tolerance, behavior and performance of firms. However, a country, may consist of many narrow local markets that can be quite heterogeneous with respect to economic conditions as well as bribery practices. A small furniture firm located in a rural area, for instance, may face a different demand and provide a different supply of bribes than a large retail firm located in the capital. In this paper I focus on a local market which is comprised of firms sharing a similar size, area of economic activity (industry) and location. This local market can be characterized by a specific bribery level and the bribing behavior of firms, which I term 'local bribery environment'.

The notion of 'local bribery environment' is aligned with the arguments of Svensson (2003) and Fisman and Svensson (2007) that bribery is industry and region specific. They suggest that a firm depends more on public officials, and therefore might have to pay higher bribes (or more often), if it requires more permits and licenses due to the specifics of its economic activity, and/or if it is located in a place with a monopolized (Drugov, 2010) or greedy public office. Hence, in a local market firms likely meet a specific average local bribery level. ${ }^{6}$ If the "grease the wheels" hypothesis is valid, then one would expect a positive relationship between local bribery level and firm performance.

However, it is unlikely that all firms in a local market always bribe equally. For illustration, two types of bribing behavior can be broadly distinguished, even and uneven. Even behavior would assume that all firms participate in bribery equally. Uneven behavior would suggest that there are both firms that bribe frequently and firms that bribe rarely or do not bribe at all in a local environment.

There can be various reasons for the (un)evenness of firms' bribing behavior. Among them are firms' differences in "willingness to pay" bribes (Bliss and Tella, 1997; Svensson, 2003) - their profitability and value of outside options as well as differences in the costs of paying bribes. The latter may be largely associated with ties to public officials and political parties (Collins et al., 2009). In countries with pervasive corruption, such as Russia and Ukraine, the tendency or even necessity to follow other firms in bribing in order to survive, can add to the evenness of bribing behavior. In these countries too, presence of firms with foreign ownership or with foreign partners can contribute to unevenness, because they usually have better management standards and stricter attitudes towards corruption. The ex-

\footnotetext{
${ }^{6}$ This can be thought of as some equilibrium level of bribery, defined as the bribery demand from public officials and average firms' ability to supply bribers in a local market.
} 
isting literature reports that firms with foreign ownership, and those that engage in importing or exporting, tend to bribe less (Svensson, 2003; Luo and Han, 2008). Among other factors defining (un)evenness can be differences in the presence of honest and dishonest firms and/or public officials, and asymmetry of information about a local environment. All these factors, however, are not necessarily independent of those that determine average bribery level, making the bribing level and behavior of firms interrelated in a local environment.

To see the possible impact of local bribery environment on firm performance, consider the following cases. If, in an even local environment, firms do not bribe, they operate in a market virtually without "frictions," and therefore can perform naturally at their best. They wait an average time to obtain public services. But if all firms bribe with the same non-zero frequency, bribes can be seen as an additional fee for public services. These firms again wait an average time to obtain public services, but because the costs are higher, they may perform worse compared to the bribe-free situation.

The performance of firms in an uneven local environment is less straightforward. If bribery works as a "grease the wheels" instrument by decreasing the waiting time to obtain public services and thereby improving firm performance, at least for the majority of bribing firms, then bribing should be the best response to bribery demands from public officials. But, given that a portion of firms does not bribe in an uneven environment, it can be hypothesized that bribing firms are competing with more productive non-bribing firms 77 By this case firm performance in more uneven environments can be higher than in bribe-free environments. However, if bribery helps only a minority of firms, yet induces red tape and negative externalities, then firms may perform worse in more uneven environments. In the paper I test these conjectures.

\section{Data and merging}

\subsection{Data sources}

The firm-level financial data comes from the Amadeus database and data on bribery is taken from the BEEPS.

The Amadeus database is a product of Bureau van Dijk. It consists of full and standardized information from the balance sheets and profit-loss account items,

\footnotetext{
${ }^{7}$ Hanousek and Palda (2009) make a similar conjecture and report some evidence of it by evaluating a displacement deadweight loss from tax evasion. They also show a possible crowding out effect by the majority of either honest or tax evading firms.
} 
industry codes and exact identification of European firms $8^{8}$ Amadeus has a specific feature regarding the exclusion of firms from the database. If a firm exits the market or stops reporting its financial data, this firm is kept in the database for four years, then excluded. For example, in the 2010 edition of Amadeus the data for 2006 do not include firms that exited in 2006 or before. To preserve the full sample of firms, therefore, I combine several editions of Amadeus: November 2010, May 2010 and June 2007 downloaded from WRDS (Wharton Research Data Services) as well as the August 2003 DVD update from Bureau van Dijk.

The coverage of firms varies by country in the database. Based on the number of available observations, I choose 14 CEE countries for the analysis: Slovenia, Hungary, Poland, Czech Republic, Slovakia, Estonia, Latvia, Lithuania, Bulgaria, Romania, Serbia, Croatia, Russia and Ukraine. These countries are similar, in that they started the transition to a market economy at approximately the same time. However, they are quite different in overall corruption levels, as Figure 1 shows for the Control of Corruption indicator obtained from the Worldwide Governance Indicators database compiled by the World Bank. Before starting the empirical analysis I clean the data of severe outliers and potential errors in variables (see Appendix D.1 for details). From Amadeus I use operational revenue, total assets, number of employees, EBIT, cash flow, current liabilities and long term debt, industry identification, city/town names, and exchange rates.

The BEEPS is an anonymous survey of a stratified random sample of firms, collected jointly by the World Bank and the European Bank for Reconstruction and Development for Central and Eastern European and former Soviet Union countries 9 It consists of a rich set of questions about firms' activity, market orientation, financial performance and employment as well as infrastructural, criminal, corruption, financial, and legal environments. Each wave of the BEEPS covers three preceding years; I use the last three waves completed in 2002, 2005 and 2008 10

The disadvantage of the BEEPS is missing data, especially for questions related to bribery and to a bigger extent to accounting information (sales, assets, costs, etc.). Despite the anonymity of firms, specific formulations of the questions ("typical firm like yours"), and timing of asking (questions regarding firm performance are asked at the end of the interview), respondents answer such sensitive questions reluctantly,

\footnotetext{
${ }^{8}$ Details of the Amadeus database can be found at http://www.bvdep.com.

${ }^{9}$ The data are available online either at http://www.ebrd.com/pages/research/economics/data/ beeps.shtml or https://www . enterprisesurveys.org. Data for this paper was downloaded from the latter source.

${ }^{10}$ The last wave was completed in 2008 or 2009 for different countries, but its questionnaire covers the same time period, 2005-2007 years. The first wave was completed in 1999 but as it does not include the industry codes of firms, I do not use it.
} 
or not at all. Thus, non-responses to various questions about bribery account for 10$20 \%$ of the data, and to questions about financial performance $-40-50 \%$. This can imply biased inference from the data analysis.For instance, worse performing firms may not report their accounting information and complain more about corruption. Answers to questions may also be subject to perception bias, such as managers' tendencies to complain or to be optimistic, or responses can be simply untruthful.11 To overcome these limitations I use firms' financial data from Amadeus and enrich it with the bribery measure from the BEEPS.

The bribery measure used in this paper is derived from answers to the following question: "Thinking about officials, would you say the following statement is always, usually, frequently, sometimes, seldom or never true: "It is common for firms in my line of business to have to pay some irregular "additional payments/gifts" to get things done with regard to customs, taxes, licenses, regulations, services etc." This question is the most general and neutral, and virtually the only one that occurs consistently by across all three waves 12 It also has the smallest number of non-responses relative to other questions about corruption $-10 \%$ overall. The original variable that measures bribery is categorical and takes values from 1 to 6 ; for convenience I rescale it to a variable that varies from 0 to 1.13 In this way it can be interpreted as the intensity of bribing, probability to bribe, or size of bribes of measure one. Figure 2 shows the time variation of the bribery measure across countries. It is heterogeneous across countries and decreases over time, but not significantly for some countries.

Neither the BEEPS nor the Amadeus databases, however, seem to be representative. Appendix D.2 compares these databases with data for the whole population of firms retrieved from the OECD.STAN database for eight OECD countries from my sample. The BEEPS and Amadeus significantly underrepresent micro firms with fewer than 10 employees. The distribution of firms by industry and country also differs from the OECD data. Such non-representativeness is the result of stratification rules in the BEEPS's sampling, and of the tendency to capture more visible firms in Amadeus. To observe the possible bias of the effect of bribery on firm performance due to this non-representativeness, I conduct the analysis for different subsamples of firms.

\footnotetext{
${ }_{11}^{11}$ Jensen et al. (2010), for example, find that in the WBES firms in countries with less press freedom tend not to respond or to give false answers to the question about how much corruption is an obstacle to firm growth and operation.

${ }^{12}$ The structure of the questionnaire and sampling method of firms changed in the latest 2008 wave compared to the 2002 and 2005 waves. This change encumbers the analysis of the three waves together, and is another reason for merging of the BEEPS with Amadeus.

${ }^{13}$ I rescale it by subtracting 1 from the original variable and dividing the result by 5 .
} 


\subsection{Merging the BEEPS and Amadeus databases}

Given that the BEEPS is an anonymous survey of firms it is not possible to exactly match the firms from the two databases; a more general criterion for their merging is therefore needed. To date, only two papers have attempted to combine the BEEPS and Amadeus: Anos-Casero and Udomsaph (2009) and Commander and Svejnar (2011). The former paper examines the impact of subjective business environment constraints on total factor productivity, and the latter on efficiency to generate revenue (it uses the combined dataset only as a robustness check of their main findings from the analysis of the BEEPS). Both papers use the 2002 and 2005 waves of the BEEPS and merge the data for 7-8 CEE countries. To combine the databases, the authors compute means of business constraints within defined cells and assign them to every firm from Amadeus belonging to the same cell. AnosCasero and Udomsaph (2009) define cells at the country - survey wave - size of location (capital, city with population over 1 mil, and below 1 mil) - firm size (2-49 and 50+ employees) dimension for all manufacturing firms together. Commander and Svejnar (2011) define cells at the country - survey wave - industry (2-digit code) - firm size (2-49, 50-249 and 250+ employees) level.

In this paper I merge the databases in a similar fashion as these authors, but employ more complex merging criteria that combine the approaches of both papers. Specifically, I use both the size of location and 2-digit industry codes to define the merging criteria, since they might be equally relevant for determining a local bribery level (Svensson, 2003; Fisman and Svensson, 2007). In contrast to these authors, I separate micro firms with fewer than 10 employees from small firms with 11-49 employees. This is motivated by the fact that originally nearly $45 \%$ of firms in the BEEPS and $40 \%$ of firms in Amadeus are micro (see Appendix D.2). Moreover, micro firms might be exempted from some bureaucratic regulations and taxes (EC, 2011), and consequently they might meet public officials less often. Finally, in contrast to Commander and Svejnar (2011) and in line with Anos-Casero and Udomsaph (2009), I join together firms with 50-249 and greater than 250 employees to capture more cells with the adequate number of firms for averaging.

The merging criteria are the following:

- country;

- time period - 1999-2001, 2002-2004, 2005-2007 corresponding to the three waves from the BEEPS;

- industry - two-digit ISIC rev 3.1 industry identification;

- firm size - micro firms with 2-10 employees, small firms with 11-49 employees, and medium and large firms with more than 50 employees; 
- location size - capital, city with population above 1 mil, and all others below 1 mil.

These merging criteria explain $40 \%$ of the total variation of the bribery measure in the BEEPS 14 Each cell is required to have at least 4 firms; there are 1137 cells in total. I compute the mean and standard deviation ${ }^{15}$ of the bribery measure for each cell defined on the intersection of country - time period - industry - firm size - location size from the BEEPS, and assign them to every firm from the same cell from Amadeus ${ }^{16}$ Given the nature of the data, the mean and standard deviation are the best ways to describe bureaucratic corruption in a local market - bribery level and dispersion or (un)evenness of the bribing behavior of firms. ${ }^{17}$ A small standard deviation suggests more even bribing behavior of firms - they either do not bribe, or bribe with the same frequency. A high standard deviation indicates more uneven behavior - some firms never or seldom bribe, while others bribe very often. As an example, all firms with more than 50 employees, located in Prague and occupied in retail trade (this defines the local market) during 1999-2000 are assumed to face the same bribery level (the mean of the bribery measure) and bribe evenly (if the standard deviation of the bribery measure is small) or unevenly (if the standard deviation is high).

The merging criteria defining a local bribery environment coincide with the arguments of Svensson (2003) and Fisman and Svensson (2007), that bribery is industry and region specific, although with one caveat. Instead of region I use size of location and basically distinguish between capitals and all other towns ${ }^{18}$ because the identification of regions is not consistently available in the BEEPS. This assumes that the characteristics of public officials are the same across towns in the countryside. While this assumption may be plausible for small countries such as Slovenia or Estonia, it is unlikely hold in large countries such as Russia or Ukraine. As a robustness check, therefore, I show that the results of this study hold for a subsample of firms located

${ }^{14}$ This result is $R^{2}$ obtained from the analysis-of-variance (ANOVA) with bribery measure as a dependent variable and all interactions between country, year, industry, firm size, and location size as independent variables.

${ }^{15}$ Anos-Casero and Udomsaph (2009) and Commander and Svejnar (2011) do not deal with the standard deviation of business constraints within cells.

${ }^{16}$ Ideally, it is important to ensure a similar structure of the BEEPS and Amadeus data within cells. This can be done by re-weighting the bribery level and dispersion measures to reflect the composition of firms from Amadeus. However, there is not much room for this, since Amadeus consists of the financial characteristics of firms and the BEEPS suffers from their extensive nonreporting. I attempted to re-weight bribery data using only the distribution of young and old firms from Amadeus; as demonstrated in section 5.4, this does not affect the results much.

${ }^{17}$ Mean and standard deviation, however, are dependent on each other. A higher mean tends to be associated with a higher standard deviation, but if, for instance, the mean approaches to one (all firms bribe at the highest frequency in a local market) the standard deviation decreases to zero.

${ }^{18}$ There are cities with a population above 1 mil only in Russia and Ukraine. 
in the capitals of countries only and for the case when size of location is omitted from the merging criteria. In addition to industry and location, I use firm size as a criterion, since firms of different sizes may face different bribery demand and are able to supply different bribes.

Besides recovered financial data of firms, the advantage of the BEEPS-Amadeus dataset is the reduction of measurement error and firm-specific perception in the bribery level measure by averaging them out. Averaging, however, does not solve the problem of missing values in the bribery measure. As a robustness check, therefore, I estimate weighted regressions with weights equal to the proportions of non-missing to total number of observations in the cells defined above. Another advantage of the BEEPS-Amadeus dataset is the alleviation of the endogeneity between firm performance and bribery by utilizing independent datasets and controlling for firm fixed effects, which I discuss in the methodology section.

The BEEPS-Amadeus dataset results in unbalanced panel data for nine years 1999-2007, where the bribery measure remains constant over three-year periods: 1999-2001, 2002-2004 and 2005-2007. Only 2 cells out of 1337 from the BEEPS have no counterparts in Amadeus. About $48.2 \%$ of observations from Amadeus have merged. ${ }^{19}$ Table 2 compares the composition of the Amadeus and BEEPSAmadeus datasets by firm size and country. After merging, the distribution of firms shifts towards micro and small firms for nearly all countries, and also shifts slightly towards Poland, Romania, Russia and Ukraine, because there are more cells from the BEEPS corresponding to these size classes and countries.

Tables 3 and 4 compare the distribution of the number of observations, the local bribery level and bribery dispersion measures by each category included in the merging criteria in the BEEPS and BEEPS-Amadeus datasets. These tables show again, for example, that the distribution of firms shifts towards Romania, Russia and Ukraine, smaller firms, and the wholesale trade industry in the BEEPS-Amadeus dataset. This shift occurs due to higher coverage of firms in Amadeus belonging to these countries, size classes and industry. The last two columns of Tables 3 and 4 show the average real sales growth and labor productivity growth. Tables 5 and 6 offer further summary statistics of the employed variables and pairwise correlations between them. Detailed definitions of the variables are in Appendix D.3.

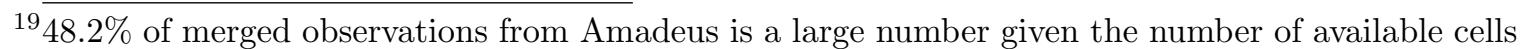
from the BEEPS. If the number of 2-digit industries is 30 , the number of countries is 14 , the number of firm size classes is 3 , the number of location types is 2 ( 3 for Russia and Ukraine) and the number of time periods is 3 , then the total number of cells should be 7520 to cover virtually all firms from Amadeus. However, the limited coverage of firms in the BEEPS and the requirement of having at least 4 firms in a cell give only 1337 cells in total. 


\section{Empirical methodology}

Theoretical reasoning suggests the possibility of both positive and negative consequences of bribery on firm performance depending on various firm characteristics, country, and local environments. This paper aims to assess empirically which effect prevails in CEE countries on average. Identification of the relation between bribery and firm performance, however, is not straightforward because of possible endogeneity. On the one hand, bribery may influence firm performance by increasing or reducing constraints to operation and growth. On the other hand, better performing firms may have a greater willingness and ability to pay bribes. This reverse causality may likely be induced by a third unobservable factor that correlates with both firm performance and bribing practices, such as managerial talent or firm culture.

In the context of the present paper this endogeneity problem is reduced due to several factors. First, the bribing behavior of individual firms is unobserved. Instead, I employ more aggregated measures of bribery, namely its average level and the (un)evenness of the bribing behavior of firms in a local market, as defined by industry, firm size, and location size characteristics. Arguably, an individual firm may have only a negligible influence on these aggregate measures ${ }^{20}$ This influence is decreased further when firm performance and bribery measure come from different independent data sources (Anos-Casero and Udomsaph, 2009). More importantly, the panel structure of the data allows me to use firm fixed effects and remove timeinvariant unobservable factors that could potentially cause both firm performance and bribing behavior.21 The short length of the panel increases the likelihood of these unobservables being fixed over time. Nevertheless, in the next section I first compare the estimates identified from within-firm variation with the estimates identified from within-cell variation to demonstrate the reduction of the endogeneity bias. In the within-cell dimension, average firm performance more likely affects cell-level bribery inducing upward bias of the estimates (if better performing firms are ready to bribe more frequently). It is worth mentioning, however, that firm fixed effects estimation does not account for temporal reverse causality, since firms may endogenously choose their location and their area of economic activity at start-up depending on how bad

${ }^{20}$ In view of the difficulties to find appropriate instruments for bribery measures, the use of industrylocation or industry-location-firm size average measures of bribery or obstacles to firm growth and operation instead of firm-specific measures is a handy approach to reduce the endogeneity problem in existing research, which employs cross-sectional data from the BEEPS, WBES or IC (Investment Climate). See, for example, Dollar et al. (2005), Kinda et al. (2009), Aterido et al. (2011) and Commander and Svejnar (2011).

${ }^{21}$ Controlling for firm fixed effects is a general approach in studies involving financial panel data analysis due to the huge heterogeneity of individual firms and possible endogeneity between variables (see, for example, Chi, 2005; Hanousek et al., 2007; Del Carpio et al., 2012). 
corruption environments are. This limitation remains open.

Before starting the regression analysis, I transform the data from a nine-year span to a three-period span and consider dependent variables as averages over three time periods 1999-2001, 2002-2004, and 2005-2007 and control variables at the beginning of each period (i.e. at 1999, 2002, or 2005). This aligns the financial data with the measures of bribery level and (un)evenness of bribing behavior, which change only over these three time periods.

The empirical specification is a typical growth equation, originally proposed by Evans (1987), where the dependent variable is the growth rate and the independent variables are lagged to control for initial conditions, ${ }^{22}$ as follows:

$$
y_{i t}=\beta_{0}+\beta_{1} \text { Bribery Level } \text { Let }_{2}+\beta_{2} \text { Bribery Dispersion }_{c t}+\gamma X_{i t-1}+v_{i}+\nu_{t}+\varsigma_{s}+\varepsilon_{i t},
$$

where $y_{i t}$ is the performance measure of firm $i$ at time period $t$; it is either real sales or labor productivity average growth rates. Bribery Level ${ }_{c t}$ and Bribery Dispersion B $_{c t}$ are the mean and standard deviation of the bribery measure from the BEEPS in cell $c$ respectively; they reflect the bribery level and the (un)evenness of bribing behavior of firms in a local market $c{ }^{23} X_{i t-1}$ is the vector of control variables. The term $v_{i}$ removes unobserved firm fixed effects that can create across-time correlation of the residuals of a given firm (e.g. managerial skills). The term $\nu_{t}$ removes unobserved time fixed effects that can be responsible for correlation of the residuals across different firms in a given year (e.g. aggregate shocks or business cycle). The term $\varsigma_{s}$ captures unobserved firm size fixed effects (micro, small, and medium-large firms) ${ }^{24}$ that can lead to correlation of the residuals across firms of a given size class due to, e.g., specific regulations attached to firms of a particular size; $\varepsilon_{i t}$ is the i.i.d. random component. I use demeaning of the variables to remove firm fixed effects, which is equivalent to the inclusion of firm identification dummies into regression, and I use dummies for time periods and firm sizes to remove corresponding fixed time and firm size effects.

The coefficients of interest are $\beta_{1}$ and $\beta_{2}$. Their positive signs would favor the

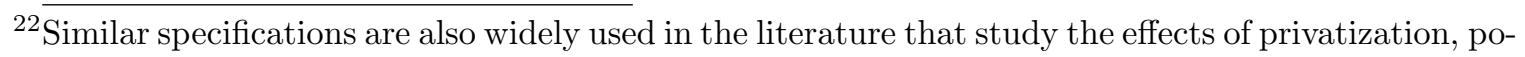
litical connections, and other events on firm performance (e.g. see Hanousek et al., 2007; Boubakri et al., 2008)

${ }^{23}$ These two statistics, the mean and standard variation of the bribery measure from the BEEPS, jointly work as the coefficient of variation $\left(c_{v}=\sigma / m\right)$. I do not use the coefficient of variation variable instead, since it is less clear to interpret the estimates of this variable.

${ }^{24}$ I control for firm size fixed effects, because firm size is included in the merging criteria. The remaining factors from the merging criteria are removed when firm fixed effects are taken into account. Exclusion of firm size fixed effects, however, does not affect the final results since the number of employees is among the independent variables. 
"grease the wheels" hypothesis of corruption. It has to be emphasized, however, that these coefficients show the effect of a local bribery environment on firm performance, while the bribing behavior of individual firms is unknown.

To construct firm performance measures, I first take the natural logarithms of real sales (approximated by operational revenue in 2000 prices) and labor productivity (real sales per employees) ${ }^{25}$ Then I compute first differences of these logarithms, which stand for the logarithmic approximation of the yearly growth rates of sales and labor productivity. $y_{i t}$ is the average of yearly growth rates over the three-year periods 1999-2001, 2002-2004 and 2005-2007. I expect that a local bribery environment may have a somewhat different effect on these performance measures. Sales is a more "visible" and immediate outcome, and unaffected directly by other financial incomes and taxes of a firm. Bribery can retard or speed sales growth, for example, through delays or expediting of investments in developing or selling new products, or export opportunities. Labor productivity in addition reflects employment structure, and therefore can be seen as performance on a longer horizon.

Vector $X_{i t-1}$ is the set of firms' characteristics. They are not actually lagged, but are measured at the beginning of each time period (i.e. at 1999, 2002, and 2005) to control for the initial conditions, to reduce possible endogeneity between them and firm performance measures and to keep all three time periods in the analysis. $X_{i t-1}$ includes logarithms of total assets and number of employees as well as their squares to control for firm size and its possible non-linearity; market share (at the 4-digit industry level); firm profitability (EBIT over total assets); book leverage ratio (total debt over total assets); and cash flow also scaled by total assets. These variables can correlate with firm performance and with bribery level and its dispersion, thus reducing omitted variable bias of the coefficients of interest. Firms with lower market shares, for instance, can be more engaged in bribery in order to survive on the market. Luo and Han (2008) report such a correlation in a study of the determinants of bribery and graft using the BEEPS for several developing countries. More profitable firms may have a higher "willingness to pay" and can pay bigger bribes and/or more frequently (Bliss and Tella, 1997; Svensson, 2003). Firms' leverage can also correlate with bribery if unofficial payments are needed to borrow finance (Beck et al., 2005). Availability of cash can also leave a bigger opportunity for bribe payments. Controlling for these firm-specific variables also eliminates differences between firms across countries and restricts the sample to

${ }^{25} \overline{\mathrm{I} \text { do not measure productivity as TFP }}$ (total factor productivity) or value added per employee, because Amadeus has many missing values in the intermediate material and staff cost variables for CEE countries; Russia, Latvia and Lithuania do not report them at all. I use a simplified version of productivity, which allows firms' capital and intermediate costs to be flexible. 
those that report all essential financial information.

Although controlling for firm fixed effects reduces the endogeneity bias of the estimates, they might still be biased because of measurement errors in the bribery level and dispersion variables. Under the assumption of classical measurement error the coefficients are biased toward zero ${ }^{26}$ and they can be biased in any direction if this assumption is violated. If measurement error of the bribery measure from the BEEPS has zero mean within cells, then in the bribery level variable this error is eliminated. This is not the case, however, for the bribery dispersion variable. Therefore, possible bias in the coefficients should be kept in mind when interpreting the results.

I estimate specification (1) using standard errors robust to heteroskedasticity and clustered at the firm level (Petersen, 2009). In addition, I account for influential observations using Cook's distance, ${ }^{27}$ as the data for CEE countries is highly volatile. Observations for which this distance exceeds $4 / N$, where $N$ is the number of observations used in the regression, are removed as outliers. This procedure improves the fit of the regressions, but does not affect the estimates much, as is shown in section 5.4.

The estimates from the fixed effects regression capture firms' dynamics. Therefore, it is important to see why the local bribery level and the (un)evenness of firms' bribing behavior in a local market can change over time. On the one hand, changes may come from the local government side. The local government may impose stricter law enforcement and reduce the opportunity for public officials to extract bribes. The changes, of course, can move in the other direction, when the local government exposes opportunistic behavior due to some exogenous shocks. There may be also the changes occurring in the local political party or government which can lead to losing (or gaining) connections between firms and public officials. On the other hand, firms themselves can change their attitudes towards bribery over time. For example, they may increase their involvement in bribery strategically to gain competitiveness, or might decrease this involvement to preserve their reputation.

Yet another factor adding noise to changes in a local bribery environment over time may be a change in the distribution of firms, including firms with foreign ownership and foreign partners, in the BEEPS database. This can be especially problematic in the last time period, since the sample stratification of the BEEPS

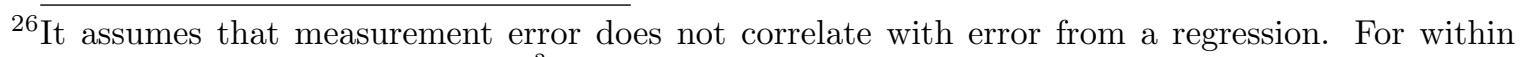
estimator plim $b=\beta\left(1-\frac{T-1}{T} \frac{\sigma_{v}^{2}}{\operatorname{var}(\tilde{x})}\right)$, where $\beta$ is a true estimate, $T$ is a maximum time dimension, $\sigma_{v}^{2}$ is a variance of measurement error and $\operatorname{var}(\tilde{x})$ is a variance of demeaned variable $x$ (Griliches and Hausman, 1986).

${ }^{27}$ Cook's distance is a measure based on the difference between the regression parameter estimates $\hat{\beta}$ and what they become if the $i$ th data point is deleted $\hat{\beta}_{-i}$, see Cook (1977) for details. 
has been changed. To see whether this affects the results, I estimate specification (1) separately for the first and second, and the second and third time periods. In addition, I compute the local bribery level variable from the BEEPS's bribery measure keeping constant such firm characteristics as foreign ownership, export and firm age to ensure a stable structure of the BEEPS data within cells, and then use it instead of the usual bribery level variable in the regression. ${ }^{28}$ The results of these estimations are reported in section 5.4.

\section{Results and discussion}

\subsection{General results}

Table 7 reports the results of the estimation of specification (1) for the whole sample of firms. Odd columns present the results for the dependent variable, real sales growth, and even columns, for labor productivity growth. The last rows of the table show the average effects of bribery level and dispersion on firm performance as well as their sum. ${ }^{29}$ In columns I-IV only time, country, industry, location, and firm size fixed effects (those that are in the merging criteria) are controlled. In columns VVIII firm, time, and firm size fixed effects are controlled. If better firm performance is generally associated with higher participation in bribery, then the coefficients on bribery level in within-cell regressions (columns I-IV) should be biased upward, because cell-average firm performance may more likely affect cell-level bribery ${ }^{30}$ Controlling for firm fixed effects should remove or at least reduce this bias. Indeed, the coefficients on bribery level are smaller in columns V-VIII than in columns I-IV, advocating for the use of firm fixed effects regressions. Further, the comparison of columns I-II with III-IV and of columns V-VI with VII-VIII shows that the inclusion of bribery dispersion does not affect the sign and significance of the coefficient on bribery level, although these variables are well correlated (see Table 6).

Having the regressions from columns VII and VIII as benchmarks, all else being equal, the jump from zero bribery level to unity in a local environment over time is associated with a $9.6 \%$ and $13.9 \%$ decrease in real sales and labor productivity

${ }^{28} \overline{\text { This correction, however, does not work }}$ for the bribery dispersion variable, since it is available on the cell-level an attempt to correct for the stable structure of the BEEPS would take out too much variation from the original variable.

${ }^{29}$ The average effect of the variable is a product of the corresponding estimated coefficient and the average value of bribery level or bribery dispersion. For example, the average effect of the bribery level on sales growth is $(-0.096 \cdot 0.311) \cdot 100 \% \approx-2.97 \%$, where -0.096 is the estimate of the coefficient on bribery level and 0.311 is the mean of bribery level variable.

${ }^{30}$ For the bribery dispersion measure the direction of bias is more difficult to determine, therefore, I do not discuss it. 
growth respectively. The increase in the bribery level by its average value is associated with a $3.0 \%$ and $4.3 \%$ decrease in corresponding firm performance measures. These numbers are relatively large, since the average real sales growth is $4.7 \%$ and the average labor productivity growth is $-3.0 \%$. The results thus show that bribery is a burden for an average firm, which is consistent with most previous findings at both the micro (Fisman and Svensson, 2007; De Rosa et al., 2010) and macro (Mauro, 1995; Campos et al., 2010) levels.

The estimates of the coefficients on bribery dispersion, in contrast, are positive for both dependent variables. They are also highly significant. For a given level of bribery, the move from zero bribery dispersion (even bribing behavior) to unity (fully uneven bribing behavior of firms, although bribery dispersion never reaches unity given that the original bribery measure from the BEEPS varies from 0 to 1 ) in a local environment over time is associated with a $17.4 \%$ and $21.9 \%$ increase in real sales and labor productivity growth respectively. The average bribery dispersion effects are $4.7 \%$ and $5.9 \%$ for the two performance measures. The sum of the average bribery level effect and the average bribery dispersion effect (in other words, the trade-offs between these two effects) is positive and equal to $1.7 \%$ for sales growth and to $1.6 \%$ for labor productivity growth 31

The results suggest that while a higher bribery level retards sales and labor productivity growth, firms benefit from bribery, on average, if they operate in more uneven local environments. An explanation for this result could be the following. In a more uneven local environment, under a given level of bribery, firms that are more efficient in bribery - that is, those that have more information about opportunities to grease the business, with lower costs or higher willingness to bribe apparently bribe more frequently than their peers. Owing to bribes and overcoming bureaucratic constraints, they most likely generate higher sales and labor productivity growth rates than if they were not to bribe. Their non-bribing (or less frequently bribing) counterparts must be more efficient in production and growth to compete with bribing firms. In this case both types of firms are able to generate, on average, increasing sales and labor productivity growth rates. Public officials, in turn, seem to be less monopolized in such an environment. Due to these facts, negative externalities from bribery seem to be negligible in uneven local bribery environments. This explanation, however, should be treated with caution, since we do not observe the bribing behavior of individual firms. It still might be the case that bribing firms exhibit increasing growth rates while their non-bribing counterparts exhibit

\footnotetext{
${ }^{31}$ These trade-off positive numbers are rather conservative. Given that bribery level and dispersion are dependent on each other, when bribery level is at its average value, bribery dispersion is higher by 0.04 than its average value as reported in Table 3 .
} 
decreasing rates, or the other way around, but on average these rates are increasing.

Another way to see why the growth rates may be slower in more even environments, recall that for a given level of bribery either the number of bribing or non-bribing firms dominates. If the number of bribing firms prevails, a negative externality from bribery (such as, for instance, incentives to induce bureaucratic burden by public officials) can occur slowing down the average growth rates. If the number of non-bribing firms dominates, then there can be fewer incentives for firms to be more efficient in production, grow fast and compete aggressively with occasionally bribing firms.

The results also show that the effects of bribery level and (un)evenness of bribing behavior seem to be more sound for labor productivity than for sales growth rates. This suggests that participation in bribery affects the employment structure of firms. In highly corrupt environments, firms likely employ a non-optimal number of workers due to the misallocation of talent, in accordance with Murphy et al.'s (1991) theory. A part of employees may be engaged in unproductive activity: searching for ways to circumvent rigid laws and bureaucratic constraints, and bargaining with public officials. It may also by the case that public officials, having established a connection with a firm, do not allow the firm to dismiss its workers in order to keep high employment figures in the region and loyal voters to the current government. However, bribing firms that have an opportunity to gain a competitive edge over their non-bribing counterparts (in more uneven local environments) are able to adjust the employment structure to an optimal level and increase effectiveness.

The results thus show that bribery can work as the "grease the wheels" instrument, in spite of its overall damaging effect. This fact, perhaps, is keeping bribery attractive for some firms. The following subsections examine the effect from bribery with respect to the heterogeneity of firms and environments to understand better what drives the relation between bribery and firm performance. The last subsection describes several robustness checks.

\subsection{Heterogeneity of firms}

\subsubsection{Manufacturing and service firms}

In the BEEPS-Amadeus dataset, firms from manufacturing sectors represent only $14.5 \%$ of the sample. On average, they tend to have lower sales growth, much higher labor productivity growth, and pay bribes less often than firms from service sectors (see Table 4). Columns I-IV, Panel A in Table 8 present the results of the estimation of specification (1) for manufacturing and service firms separately 
(construction industry is not included). The estimated coefficients on bribery level and its dispersion are drastically different for the two subsamples of firms.

Higher levels of bribery in local environments significantly retard the performance of manufacturing firms, especially real sales growth. Operating in more uneven environments does not bring benefits either (see columns I-II, Panel A in Table 8). Large size of manufacturing firms can make them more visible and attractive for public officials eager for additional, though unofficial, incomes. At the same time it can make them less flexible in responding to the bribery level and leave a lower capacity to extract benefits in uneven local environments. Manufacturing firms also tend to have a larger share of foreign ownership, which is usually associated with higher management standards leading to stricter attitudes against corruption and hence, perhaps, a poorer ability to deal with it.

Another explanation for the result may be that the utilized bribery measure does not reflect well the nature of bribing practices among manufacturing firms, if any. These firms arguably require fewer permits, licences, and inspections than do service firms (compare, for instance, a furniture firm with a restaurant that has to comply with food quality standards), but might depend more heavily on the relationships with customers and supply chains. Their corruption practice, therefore, might instead consist of kickbacks between businesses. Service firms, in contrast, are smaller, more flexible, and likely interact more often with public officials. Although on average they suffer as well from higher bribery levels, they are able to gain significantly in local market with more uneven bribing behavior of firms (columns III-IV, Panel A in Table 8). This story, however, does not end for service firms.

As Table 4 demonstrates, approximately a half of the sample belongs to the wholesale and retail trade industries ( $79 \%$ of service firms), and $15 \%$ belongs to the construction sector. Construction, and to a lesser extent, wholesale trade firms tend to pay bribes more frequently than service firms on average; retail trade firms, slightly less. Columns V-VI, Panel A in Table 8 show the results of the estimation of specification (1) for the subsample of service firms excluding these sectors, and Panel B in Table 8 displays the results for the subsamples of these sectors separately. The estimates show that construction, wholesale, and retail trade firms, particularly, drive the results for the whole sample, i.e. losses in growth rates from the higher bribery level and gains from the uneven bribing behavior of firms in local environments. For the remaining service firms the outcome is the opposite.

Given that the BEEPS-Amadeus dataset is not representative (for OECD countries, for example, firms from the construction and wholesale sectors are overrepresented in comparison with OECD.STAN data, see Appendix D.2 and Table 4) 
it seems that the estimated magnitudes of the coefficients on bribery level and its dispersion presented in Table 7 are biased upward in absolute values.

\subsubsection{Firm size}

The literature usually documents that corruption is a bigger obstacle for micro and small firms than for large firms, and hence impedes the performance of smaller firms more (e.g. UNIDO/UNODC, 2007; Beck et al., 2005; Aterido et al., 2011). This is explained, for example, by the fact that smaller firms have weaker bargaining power and influence on public officials. They also have more difficulties obtaining finance due to having smaller collateral. In this paper, however, the bribery level variable measures frequency of paying bribes 'to get things done' and may not reflect corruption as an obstacle. Indeed, Table 3 reports that the bribery level increases with firm size. Therefore, I do not expect the same results as the cited literature suggests.

Panel A in Table 9 presents the results of the estimation of specification (1) for three subsamples of micro, small and medium plus large firms. The signs of the coefficients on bribery level and its dispersion are the same as in the case for the whole sample; the magnitudes, however, are different for the three subsamples. It turns out that the growth rates of micro firms are the least affected by bribery, large firms suffer the most from higher bribery levels, and small firms are able to extract the greatest benefits in more uneven local environments.

One explanation for this finding is that firms of different class size carry different levels of regulatory burden. These differences usually are designed to promote the growth and development of small businesses and encourage entrepreneurship (World Bank, 2004). Thus, smaller (micro) firms are often required to comply with softer regulatory standards and requirements such as reporting and keeping records for inspections. They may also be exempted from some taxes, or have lower tax rates. Labor, health, and safety inspections can also have a negligible effect on smaller firms. In addition, smaller amounts of bribes can be extracted from firms with smaller numbers of employees and turnover.

These outcomes confirm the conjecture in section 5.2.1 that the estimated coefficients on bribery level and its dispersion presented in Table 7 are likely biased upward in absolute values. This is because the actual share of micro firms is at least twice as big in the representative OECD data than in the BEEPS-Amadeus dataset (see Appendix D.1). 


\subsubsection{Firms' dynamics}

As Table 3 shows, the number of firms is increasing over time in the BEEPSAmadeus dataset. This short panel dataset also captures some firms' dynamics. Taking advantage of this feature, I examine whether bribing practices affect the performance of new entering, exited and stable firms differently. About $8.5 \%$ of firms remain in the sample during all three periods, $24.8 \%$ of the sample are new firms that appear in the second period and stay in the third, and only $3.3 \%$ are those that have exited from the sample in the last period. The remaining firms are present in the sample only in the one time period, or only in the first and the third, are not considered in this subsection. The number of entering and exited firms in the BEEPS-Amadeus dataset, however, is a rough approximation of actual firms' dynamics.

Table 1 below presents summary statistics for three subsamples of firms: stable, entering, and exited. Entering and exited firms on average pay bribes more frequently, have lower sales growth, and more volatile growth rates. Entering firms have negative and exited firms have large positive labor productivity growth rates, suggesting that the former are increasing (hiring) and the latter are decreasing (firing) the number of employees.

Table 1: Firms' dynamics

\begin{tabular}{lccccccccc}
\hline & \multicolumn{3}{c}{ Stable } & \multicolumn{3}{c}{ New entering } & \multicolumn{3}{c}{ Exited } \\
\cline { 2 - 10 } & Mean & Median & S.D. & Mean & Median & S.D. & Mean & Median & S.D. \\
\cline { 2 - 10 } Sales growth & $3.55 \%$ & $3.55 \%$ & $30.42 \%$ & $2.08 \%$ & $1.89 \%$ & $48.43 \%$ & $0.89 \%$ & $2.82 \%$ & $43.78 \%$ \\
Lab. prod. growth & $1.98 \%$ & $1.80 \%$ & $28.70 \%$ & $-5.20 \%$ & $-5.23 \%$ & $41.67 \%$ & $7.04 \%$ & $5.56 \%$ & $42.70 \%$ \\
Bribery Level & 0.29 & 0.27 & 0.13 & 0.30 & 0.28 & 0.14 & 0.33 & 0.34 & 0.17 \\
Bribery Dispersion & 0.26 & 0.27 & 0.07 & 0.26 & 0.27 & 0.08 & 0.28 & 0.29 & 0.09 \\
\hline
\end{tabular}

Panel C in Table 9 reports the results of the estimation of specification (1) for these three subsamples. The coefficients on bribery level and its dispersion are significant and have the same signs as for the whole sample. However, bribery seems to have a stronger effect on the performance of firms that are at the beginning or at the end of their business experience. The strong negative impact of bribery levels on the growth rates of exited firms could be associated with costly bureaucratic exit procedures related to bankruptcy or retreat from the market, and final tax administrations. These firms might also attempt to fight for survival in the early stages of exit. Costly bribes for new entering firms might work for becoming established. It is notable that the trade-off between the effects of the bribery level and of the (un)evenness of bribing behavior is negative for stable firms. This fact should incite protest against corruption. 


\subsection{Heterogeneity of environments}

\subsubsection{Countries' institutional environments}

Despite countries from the CEE region having undergone transition at approximately the same time, they are quite heterogeneous with respect to overall corruption levels, as Figures 1 and 2 show. Unsurprisingly, countries that entered the European Union in 2004 (Slovenia, Hungary, Poland, Czech Republic, Slovakia, Estonia, Latvia, Lithuania) tend to have the lowest corruption levels. Russia and Ukraine are the most corrupt. This section determines whether bribery affects firm performance differently in countries with different strength of institutions.

I first estimate specification (1) allowing for the coefficients on bribery level and its dispersion to vary for three regions: first - Slovenia, Hungary, Poland, Czech Republic, Slovakia, Estonia, Latvia and Lithuania (15.5\% of the sample); second Croatia, Serbia, Bulgaria and Romania (30.5\% of the sample); and third - Russia and Ukraine (54.0\% of the sample). The first region is the least corrupt and have stronger institutions, while the third region is the opposite case. Second, I use the Rule of Law indicator from the Worldwide Governance Indicators database to proxy for countries' institutions. It captures the incidence of crime, effectiveness of the judiciary, and enforcement of contracts. I rescale this indicator to a variable that varies from 0 to 1 , where higher values stand for weaker Rule of Law. I include into specification (1) interaction terms between Rule of Law and bribery measures to see how country institutions are indirectly associated with the bribery-firm performance relationship.

Table 10 reports the results from the estimation of these specifications. Panel A shows that in all three regions firm performance deteriorates with a higher bribery level. This impact is strongest for firms from the first region. A higher probability of being caught and stricter law enforcement make bribery more painful. In more uneven local environments, however, firms from this region are able to gain the most benefits. The trade-offs between bribery level and the (un)evenness of bribing behavior, meanwhile, are positive only for the second and third regions (these are not reported in the table).

The results presented in Table 10, Panel B generally complement the finding above. They suggest that although bribery level has a negative impact on firm performance, in countries with weaker institutions this impact is less pronounces. In countries with the weakest Rule of Law indicator, such as in Serbia between 19992001, the effect of bribery level even becomes positive. The worsening of institutions also decreases growth gains from the more uneven bribing behavior of firms in local 
markets; however, they never become negative in my sample of countries since the Rule of Law indicator does not exceed unity. Table 10 thus provides some empirical evidence for the theoretical conjectures of Infante and Smirnova (2009) and De Vaal and Ebben (2011), but it contradicts the empirical evidence of De Rosa et al. (2010).

\subsubsection{Local bribery environments}

The general results show that, ceteris paribus, more uneven local environments lead to the higher economic performance of firms. In this final subsection I examine how the bribery level affects firm performance depending on the extent of the unevenness of local environments.

To do so, I roughly separate local environments into even and uneven. A dummy variable indicating an even (uneven) environment is equal to one if bribery dispersion is less than or equal to the 25 th percentile (is greater than or equal 75 th percentile) of its distribution for each country, and zero otherwise. Second, I interact these dummies with bribery level and include them in specification (1) instead of bribery level and dispersion. Columns I-II in Table 11 report the results of estimating this regression. A higher bribery level worsens both sales and labor productivity growth rates in even environments. Bribes, therefore, seem to increase the costs of operation and/or undermine incentives to grow in environments where everyone uniformly participates in bribery. In contrast, in uneven environments the possibility to bribe more often for some firms allows firms to perform better on average.

For completeness, I also test whether average firm performance is significantly different for firms that operate in uneven environments, and for those that have low and high bribery levels in even environments, than it is for all other firms that are in the middle. For this exercise, first I roughly distinguish two types of bribery levels. A dummy variable indicating a low (high) level is equal to one if the bribery level is less than or equal to the 25th percentile (is greater than or equal to the 75th percentile) of its distribution for each country, and zero otherwise. Second, I interact the even environment dummy variable with each type of bribery level, and include these dummies and a dummy for the uneven environment in specification (1) instead of bribery level and dispersion.

Columns III-IV in Table 11 report the estimates from the regression. The coefficients show that those firms that operate in even environments and pay bribes rarely, i.e. inhabit close to a bribe-free situation, have $-1.1 \%$ and $0.6 \%$ conditional average sales and labor productivity growth rates. In even environments but with a high bribery level these rates decrease to $-6.2 \%$ and $-3.6 \%$ respectively. Finally, those firms that operate in uneven environments demonstrate moderately positive 
rates $-1.0 \%$ and $1.1 \%$. Widespread corruption, therefore, largely decreases average firm performance, but unevenness of local bribery environments - increases.

\subsection{Robustness check}

As a robustness check I use another two bribery measures constructed as dummy variables from the original frequency of paying bribes. The first measure takes value one if firms report that they bribe public officials sometimes, frequently, usually or always to 'get things done', and zero otherwise, as in De Rosa et al. (2010); the second measure takes value one if firms report that they bribe seldom, sometimes, frequently, usually, or always, and zero if never. These variables only indicate participation in bribery, but not its intensity as the measure used in the main analysis. In the BEEPS-Amadeus dataset, these measures are again averaged within countrytime period-industry-firm size-location size cells and proxied for bribery levels in local environments. The (un)evenness of bribing behavior is computed as before, since the standard deviations of dummy variables do not appropriately reflect dispersion. Table 12, Panel A displays the results of the estimation of specification (1) with these new bribery measures. The estimates of the coefficients of interest are qualitatively the same as for the main bribery measure, only their magnitudes are slightly smaller. Hence, the results are not driven by the choice of bribery measure.

Although the bribery measure is consistent across all three waves of the BEEPS, the structure of the questionnaire and stratification of surveyed firms were changed in the last wave. These changes might have an impact on the results. The number of firms registered in the Amadeus database is also increasing over time, which potentially can have an effect on the results as well. To rule out these possibilities, I estimate specification (1) separately for the first and second, and for the second and third, time periods. The estimates presented in columns I-IV, Panel B in Table 12 suggest that these changes do not affect the main outcome.

Further, to ensure a stable structure of the BEEPS within cells, instead of unconditional averaging of the bribery measure from the BEEPS, I compute the local bribery level measure keeping constant such firm characteristics as foreign ownership, export, and firm age. I then use this conditional bribery level variable to estimate specification (1). The bribery dispersion variable, meantime, remains the same. As columns I-II, Panel C in Table 12 demonstrate, the main results qualitatively are the same. Taking further care of the structure of the BEEPS and Amadeus data within cells, I compute the local bribery level and dispersion variables using the bribery measure from the BEEPS multiplied by the proportions of young and old firms within corresponding cells from Amadeus. I then use these 
weighted bribery measures to estimate specification (1). The coefficients of interest only have increased in absolute values, see columns III-IV, Panel C, Table 12 .

The main analysis assumes growth rates averaged over three years and control variables measured at the beginning of three-year periods. As a robustness check I estimate specification (1) on yearly data (nine years in total) with lagged control variables, using two methods. First, I use conventional firm, firm size and time fixed effects estimation as before. Second, I include a lag of the dependent variable among the regressors to control for autocorrelation in residuals and apply Arellano and Bond's (1991) dynamic panel data estimation technique, i.e. estimate specification (1) in first differences and use second lags of independent variables (except bribery level and its dispersion, since they do not change across the tree-year periods) as instruments. Panel A in Table 13 presents the results of such estimations. The coefficients of interest are not qualitatively different from the main results, meaning that neither data structure nor possible autocorrelation drive the results.

In the main analysis I use country-time period-industry-firm size-location size cells with the number of observations no fewer than 4 in each cell to compute the means and standard deviations of the bribery measure. The higher the number of observations in a cell the better the accuracy of these statistics. Panel B in Table 13 shows the results of the estimation of specification (1) when I use no fewer than 3 observations (columns I and II) and no fewer than 5 observations (columns III and IV) in a cell. The results are qualitatively the same. The magnitudes of the coefficients of interest, however, become larger when bribery level and its dispersion are computed more accurately.

I check for sensitivity of the results to the inclusion of location size in the merging criteria. Columns I-II, Panel A in Table 14 present the results of the specification (1) estimation on the subsample of firms located in the capitals of countries $(13 \%$ of the sample). Capitals are the only cities exactly identified from both the BEEPS and the Amadeus databases. Although firms located in capitals can differ from their counterparts in the rest of the country - they tend to have higher sales growth and smaller labor productivity growth than an average firm - it is notable that the signs of the estimated coefficients on bribery level and its dispersion remain the same as in the results for the whole sample. I further estimate (1) on the merged BEEPS-Amadeus dataset, for which location size is omitted from the merging criteria. Columns III-IV, Panel B in Table 14 demonstrate that the results in this case again are qualitatively the same. These outcomes show that location size, generally, is not terribly important, but its inclusion in the merging criteria improves the fit of the models and seems to be plausible. 
In the BEEPS-Amadeus dataset the measurement error and perception bias of the original bribery measure are likely reduced by averaging out while computing the bribery level variable. This aggregation, however, does not solve the problem of missing data (about $10 \%$ of the sample in BEEPS), which could be reflected in an inaccurate bribery level and (un)evenness of the bribing behavior of firms. To check whether missing values affect the main results, I estimate specification (1) putting higher weights on cells with a higher number of non-missing observations (weight is equal to the ratio of the number of non-missing values to the total number of observations in a cell). Columns V-VI, Panel A in Table 14 show that the estimated coefficients of interest are nearly identical to those from the main analysis, ruling out the problem of missing data in the original bribery measure.

In all estimations I use Cook's distance to account for outliers and influential observations. Columns I-II, Panel B in Table 14 report the estimates without using Cook's distance. The results are qualitatively the same as before, though accounting for outliers slightly increases the magnitudes of the coefficients on bribery level and its dispersion and doubles the overall fit of the regressions.

As an addition robustness check, I use the dataset without severe outliers in variables defined as exceeding the top $5 \%$ and below the bottom $5 \%$ of the distribution, instead of the top and bottom 1\% (see Appendix D.1). I also use the dataset without data imputation (see also Appendix D.1). Columns III-VI, Panel B in Table 14 present the results of the estimations of specification (1) using these datasets. The estimates of the coefficients of interest remain virtually the same as before and, therefore, robust to the definition of outliers and imputation procedure.

Finally, I add in specification (1) variables that measure different obstacles to firms' operation and growth obtained from the BEEPS. These measures are averaged within country-time period-industry-firm size-location size cells in the same way as bribery level. By including these obstacles I check whether bribery level and the (un)evenness of bribing behavior explain the participation of firms in bribery, but not other phenomena. If obstacles and bribery variables explain the same phenomena, then the significance of the coefficients of interest should decrease. Table 14, Panel $\mathrm{C}$ presents the results when corruption, tax administration, and obtaining business licenses and permits are used as obstacles. The standard errors of the estimated coefficients of interest remain the same. Similar conclusions can be made for other obstacles from the BEEPS such as access to finance, cost of finance, infrastructure, tax, trade with customers, and labor regulation; the results for these regressions are not reported. 


\section{Conclusion}

This paper empirically studies the relation between 'local bribery environments' and firm performance in Central and Eastern European countries. To assess this relation and overcome data and methodological limitations of previous research, I combine reliable and large firm-level data from the Amadeus database with bribery practices data from the BEEPS. The latter reflects the frequency of paying bribes to public officials to 'get things done'. I compute the means and standard deviations of the bribery measure for country - survey wave - industry - firm size - location size cells using the BEEPS and assign them to individual firms from the Amadeus database belonging to the same cell.

Exploring within-firm variation, the results of the empirical analysis suggest that a higher local bribery level retards both real sales and labor productivity growth, making bribery a burden for an average firm. The increase in the bribery level by its average value is associated with a $3.0 \%$ and $4.3 \%$ decrease in corresponding firm performance measures. This outcome complements most of the existing literature that examines the consequences of corruption on the macro and micro levels. This paper, however, also finds that conditional on a given level of bureaucratic corruption a higher unevenness of firms' bribing behavior in local environments facilitates firm performance. The average bribery dispersion effects are positive and equal to $4.7 \%$ and $5.9 \%$ for the two performance measures, so that the trade-offs between bribery level and dispersion are positive too. In such environments, bribery likely helps firms which are favoured or are more efficient in bribery to overcome bureaucratic constraints. Non-bribing firms there, in turn, seem to be more efficient in production and growth. In this way firms are able to generate increasing growth rates in more uneven local bribery environments. A further finding is that the performance of firms in an uneven environment appears to be higher than in a bribe-free one. The unevenness of firms' bribing behavior in some environments can thus explain the persistence of corruption and advocate the "grease the wheels" hypothesis.

The main findings of the paper hold most strongly for construction, wholesale, and retail trade firms that comprise approximately $70 \%$ of the entire sample. The effects of a local bribery environment appear to be less sound in countries with weaker institutions, to some extent supporting theoretical conjectures of Infante and Smirnova (2009) and De Vaal and Ebben (2011). These effects also seem to be more important for firms with more than 10 employees, and for those that are at the beginning or at the end of their business experience. Although the scope of this paper does not allow me to address directly the impact of bribery on firm survival, this would be an area open to future research. 


\section{References}

Acemoglu, D. (2003). Root causes: a historical approach to assessing the role of institutions in economic development, Finance and Development 40: 27-30.

Acemoglu, D. and Verdier, T. (2000). The choice between market failure and corruption, The American Economic Review 90(1): 194-211.

Anos-Casero, P. and Udomsaph, C. (2009). What drives firm productivity growth? The World Bank Policy Research Working Paper 4841.

Arellano, M. and Bond, S. (1991). Some tests of specification for panel data: Monte carlo evidence and an application to employment equations, Review of Economic Studies 58: 277 - 297.

Aterido, R., Hallward-Driemeier, M. and Pages, C. (2011). Big constraints to small firms' growth? Business environment and employment growth across firms, Economic Development and Cultural Change 59(3): 609 - 647.

Beck, P. J. and Maher, M. W. (1986). A comparison of bribery and bidding in thin markets, Economics Letters 20(1): $1-5$.

Beck, T., Demirguc-Kunt, A. and Maksimovic, V. (2005). Financial and legal constraints to growth: Does firm size matter?, The Journal of Finance 60(1): 137177.

Bliss, T. and Tella, R. D. (1997). Does competition kill corruption?, Economic Policy 105(5): 207-218.

Boubakri, N., Cosset, J.-C. and Saffar, W. (2008). Political connections of newly privatized firms, Journal of Corporate Finance 14: 654-673.

Campos, N., Dimova, R. and Saleh, A. (2010). Whither corruption? A quantitative survey of the literature on corruption and growth. IZA Discussion Paper No. 5334.

Chi, J. D. (2005). Understanding the endogeneity between firm value and shareholder rights, Financial management 34(4): 65-76.

Collins, J., Uhlenbruck, K. and Rodriguez, P. (2009). Why firms engage in corruption: A top management perspective, Journal of Business Ethics 87(1): 89-108.

Commander, S. and Svejnar, J. (2011). Business environment, exports, ownership, and firm performance, The Review of Economics and Statistics 93(1): 309-337.

Cook, R. D. (1977). Detection of influential observations in linear regression, Technometrics 19: 15-18.

De Rosa, D., Gooroochurn, N. and Gorg, H. (2010). Corruption and productivity: Firm-level evidence from the beeps survey. The World Bank Policy Research Working Paper 5348. 
De Vaal, A. and Ebben, W. (2011). Institutions and the relation between corruption and economic growth, Review of Development Economics 15(1): 108-123.

Del Carpio, X., Nguyen, H. and Wang, L. (2012). Does the minimum wage affect employment? evidence from the manufacturing sector in indonesia. World Bank Policy Research Working Paper No. 6147.

Dollar, D., Hallward-Driemeier, M. and Mengistae, T. (2005). Investment climate and firm performance in developing economies, Economic Development and Cultural Change 54(1): 1-31.

Drugov, M. (2010). Competition in bureaucracy and corruption, Journal of Development Economics 92: 107-114.

EC (2011). Minimizing regulatory burden for smes: Adapting EU regulation to the needs of micro-enterprises. Report from the commission to the council and the European Parliament.

Evans, D. S. (1987). Tests of alternative theories of firm growth, The Journal of Political Economy 95(4): 657-674.

Fisman, R. and Svensson, J. (2007). Are corruption and taxation really harmful to growth? Firm level evidence, Journal of Development Economics 83(1): 63-75.

Gaviria, A. (2002). Assessing the effects of corruption and crime on firm performance: Evidence from latin america, Emerging Markets Review 3(3): 245-268.

Griliches, Z. and Hausman, J. A. (1986). Errors in variables in panel data, Journal of Econometrics 31: 93-118.

Hanousek, J., Kocenda, E. and Svejnar, J. (2007). Origin and concentration, The Economics of Transition 15(1): 1-31.

Hanousek, J. and Palda, F. (2009). Is there a displacement deadweight loss from tax evasion? Estimates using firm surveys from the czech republic, Economic Change and Restructuring 42: 139-158.

Huntington, S. P. (1968). Political Order in Changing Societies, New Haven: Yale University Press.

Infante, D. and Smirnova, J. (2009). Rent-seeking under a weak institutional environment, Economics Letters 104: 118-121.

Jain, A. (2001). Corruption: A review, Journal of economic surveys 15(1): 71-121.

Jensen, N. M., Quan, L. and Rahman, A. (2010). Understanding corruption and firm responses in cross-national firm-level surveys, Journal of International Business Studies 41(9): 1481-1504.

Kaufmann, D. (2005). Myths and realities of governance and corruption, pp. 81-98. Published in: Global Competitiveness Report 2005-06. 
Kaufmann, D. and Wei, S.-J. (2000). Does "grease money" speed up the wheels of commerce? IMF working paper, WP/00/64.

Khan, M. H. (2006). Governance and anti-corruption reforms in developing countries: Policies, evidence and ways forward. G-24 Discussion Paper Series, No 42 .

Kinda, T., Plane, P. and Veganzones-Varoudakis, M.-A. (2009). Firm's productive performance and the investment climate in developing economies: An application to MENA manufacturing. World Bank Policy Research Working Paper No. 4869.

Klapper, L., Laeven, L. and Rajan, R. (2006). Entry regulation as a barrier to entrepreneurship, Journal of Financial Economics 82(3): 591-629.

Leff, N. (1964). Economic development through bureaucratic corruption, The American Behavior Scientist 8: 8-14.

Lein, D.-H. D. (1986). A note on competitive bribery game, Economics Letters 22(4): 337-341.

Lein, D.-H. D. (1990). Corruption and allocation efficiency, Journal of Development Economics 33(1): 153164.

Lui, F. (1985). An equilibrium queuing model of bribery, Journal of Political economy 93: 760-781.

Luo, Y. and Han, B. (2008). Graft and businesses in emerging economies: An ecological perspective, Journal of World Business 44(3): 225-237.

Mauro, P. (1995). Corruption and growth, Quarterly Journal of Economics 110: $681-712$.

McArthur, J. and Teal, F. (2004). Corruption and firm performance in Africa. Development and Comp Systems 0409015, EconWPA.

Meon, P.-G. and Weill, L. (2010). Is corruption an efficient grease?, World Development 38(3): 244-259.

Murphy, K., Shleifer, A. and Vishny, R. (1991). The allocation of talent: Implications for growth, Quarterly Journal of Economics 106: 503-530.

North, D. (1990). Institutions, Institutional Change and Economic Performance, Cambridge University Press, Cambridge.

Petersen, M. A. (2009). Estimating standard errors in finance panel data sets: Comparing approaches, Review of Financial Studies 22(1): 435-480.

Rose-Ackerman, S. (1997). The political economy of corruption, in Elliot (ed.), Corruption and the global economy, Washington DC: Institute for International Economics, pp. 31-60. 
Sanyal, A. (2004). Bribes in a supply line, Economica 71: 155-168.

Shleifer, A. and Vishny, R. (1993). Corruption, Quarterly Journal of Economics 108(3): 599-617.

Svensson, J. (2003). Who must pay bribes and how much? Evidence from a cross section of firms, Quarterly Journal of Economics 118: 207-230.

Svensson, J. (2005). Eight questions about corruption, Journal of Economic Perspectives 19(5): 19-42.

UNIDO/UNODC (2007). Corruption prevention to foster small and medium-sized enterprise development.

Vial, V. and Hanoteau, J. (2010). Corruption, manufacturing plant growth, and the asian paradox: Indonesian evidence, World Development 38(5): 693-705.

World Bank (2004). Review of small business activities. Washington, DC: World Bank. 


\section{Figures and Tables}

Figure 1: Control of Corruption

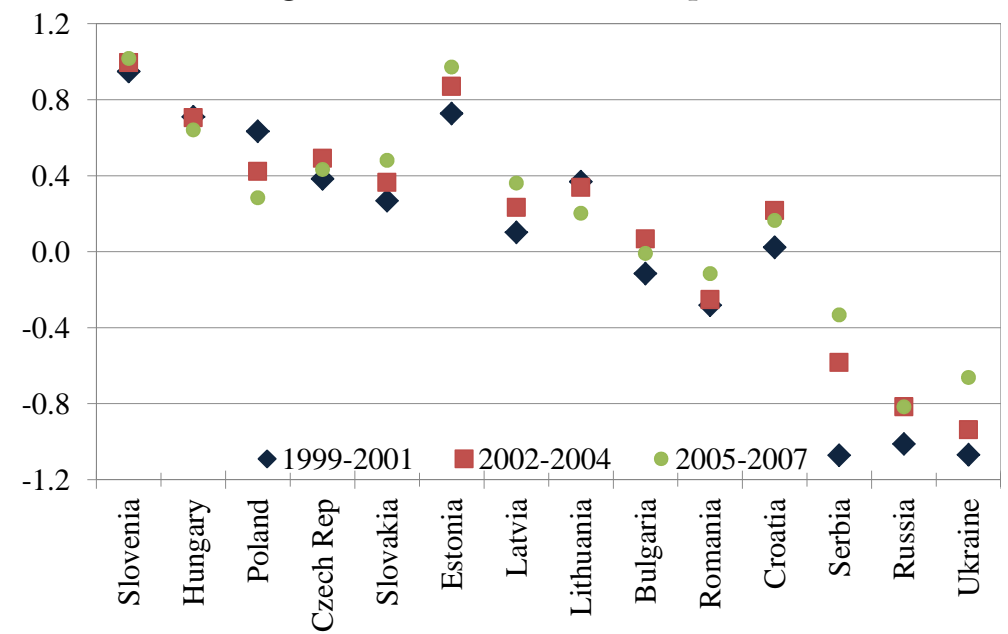

Note: Figure shows variation of the Control of Corruption indicator across countries and time periods. For each time period the average value over three years is taken. Higher values stand for lower overall corruption levels.

Figure 2: Bribery measure

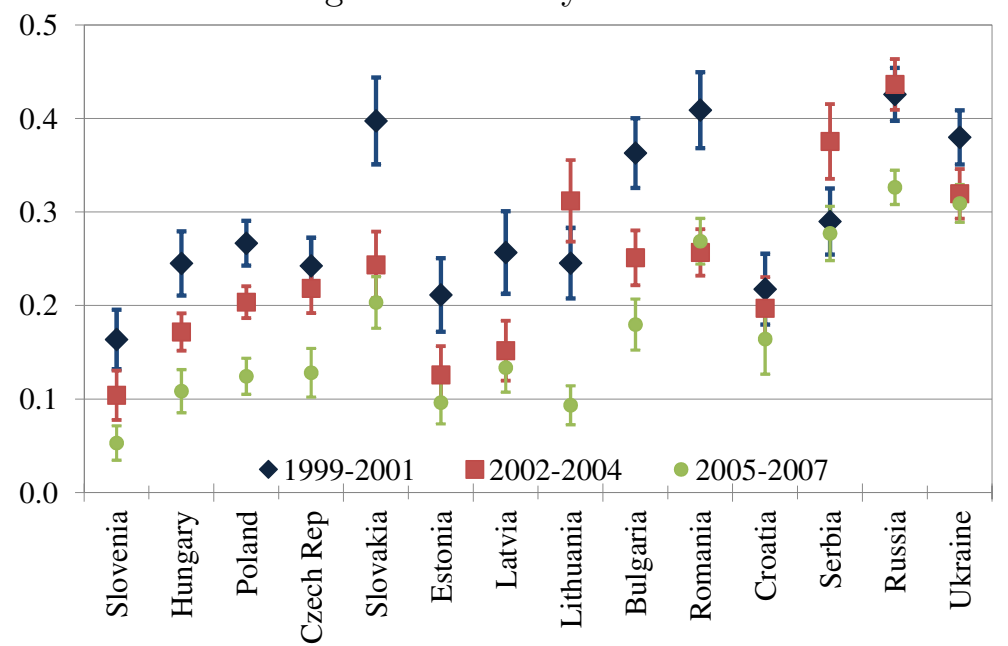

Note: Figure shows variation of the bribery measure constructed from the BEEPS, across countries and time periods. Spikes stand for confidence intervals. Higher values indicate a higher frequency of bribing, and therefore higher overall bribery levels. 
Table 2: Frequency distribution of the number of observations, in $\%$

\begin{tabular}{|c|c|c|c|c|c|c|c|c|}
\hline \multirow{2}{*}{ Country } & \multicolumn{4}{|c|}{ Amadeus } & \multicolumn{4}{|c|}{ BEEPS-Amadeus } \\
\hline & 2-10 empl & $11-49$ empl & $50+$ empl & Total & 2-10 empl & $11-49 \mathrm{empl}$ & $50+$ empl & Total \\
\hline \multirow[t]{2}{*}{ Slovenia } & 51.47 & 32.47 & 16.06 & 100 & 68.66 & 20.61 & 10.74 & 100 \\
\hline & 1.17 & 0.94 & 0.82 & 1.02 & 1.15 & 0.43 & 0.48 & 0.77 \\
\hline \multirow[t]{2}{*}{ Hungary } & 36.69 & 42.74 & 20.58 & 100 & 35.51 & 47.23 & 17.27 & 100 \\
\hline & 1.71 & 2.53 & 2.14 & 2.08 & 1.49 & 2.48 & 1.93 & 1.93 \\
\hline \multirow[t]{2}{*}{ Poland } & 13.07 & 32.34 & 54.59 & 100 & 16.41 & 33.59 & 50 & 100 \\
\hline & 1.09 & 3.41 & 10.14 & 3.72 & 1.37 & 3.53 & 11.14 & 3.85 \\
\hline \multirow{2}{*}{ Czech Rep. } & 47.27 & 31.53 & 21.2 & 100 & 56.62 & 26.79 & 16.59 & 100 \\
\hline & 5.79 & 4.9 & 5.81 & 5.48 & 5.88 & 3.49 & 4.59 & 4.78 \\
\hline \multirow[t]{2}{*}{ Slovakia } & 28.1 & 37.19 & 34.71 & 100 & 30.96 & 41.93 & 27.11 & 100 \\
\hline & 0.46 & 0.78 & 1.28 & 0.74 & 0.4 & 0.68 & 0.93 & 0.59 \\
\hline \multirow[t]{2}{*}{ Estonia } & 60.02 & 31.81 & 8.17 & 100 & 67.59 & 27.37 & 5.04 & 100 \\
\hline & 3.9 & 2.63 & 1.19 & 2.91 & 2.8 & 1.42 & 0.56 & 1.91 \\
\hline \multirow[t]{2}{*}{ Latvia } & 29.05 & 43.48 & 27.47 & 100 & 35.42 & 49.37 & 15.2 & 100 \\
\hline & 0.63 & 1.2 & 1.34 & 0.98 & 0.65 & 1.13 & 0.74 & 0.84 \\
\hline \multirow[t]{2}{*}{ Lithuania } & 26.34 & 46.16 & 27.51 & 100 & 27.95 & 51.52 & 20.53 & 100 \\
\hline & 0.58 & 1.29 & 1.35 & 0.98 & 0.53 & 1.22 & 1.03 & 0.87 \\
\hline \multirow[t]{2}{*}{ Bulgaria } & 50.38 & 34.82 & 14.8 & 100 & 57.64 & 34.25 & 8.12 & 100 \\
\hline & 6.1 & 5.35 & 4.01 & 5.42 & 6.31 & 4.71 & 2.37 & 5.04 \\
\hline \multirow[t]{2}{*}{ Romania } & 64.18 & 26.75 & 9.08 & 100 & 63 & 28.66 & 8.34 & 100 \\
\hline & 25.74 & 13.62 & 8.14 & 17.95 & 27.08 & 15.46 & 9.54 & 19.78 \\
\hline \multirow[t]{2}{*}{ Croatia } & 60.4 & 28.73 & 10.87 & 100 & 71.61 & 20.72 & 7.67 & 100 \\
\hline & 4.63 & 2.8 & 1.86 & 3.43 & 4.21 & 1.53 & 1.2 & 2.7 \\
\hline \multirow[t]{2}{*}{ Serbia } & 58.45 & 26.68 & 14.87 & 100 & 70.5 & 18.79 & 10.7 & 100 \\
\hline & 4.1 & 2.37 & 2.33 & 3.14 & 4.56 & 1.53 & 1.84 & 2.98 \\
\hline \multirow[t]{2}{*}{ Russia } & 30.34 & 41.3 & 28.36 & 100 & 28.09 & 45.81 & 26.11 & 100 \\
\hline & 21.29 & 36.79 & 44.51 & 31.4 & 19.61 & 40.13 & 48.53 & 32.14 \\
\hline \multirow[t]{2}{*}{ Ukraine } & 49.16 & 36.3 & 14.54 & 100 & 50.59 & 37.42 & 11.99 & 100 \\
\hline & 22.81 & 21.38 & 15.08 & 20.76 & 23.97 & 22.26 & 15.13 & 21.82 \\
\hline Total & 44.75 & 35.24 & 20.01 & 100 & 46.03 & 36.68 & 17.29 & 100 \\
\hline
\end{tabular}

Note: Table reports frequency distributions in \% of the number of observations by firm size (2-10 employees, 11-9 employees and more than 50 employees) and country in the Amadeus and BEEPS-Amadeus datasets. The data is cleaned of outliers (see Appendix D.2). Each white row for each country in each dataset sums to $100 \%$, and each grey column for each size category sums to $100 \%$. 
Table 3: Distribution of the number of observations, means and standard deviations of the bribery measure, and firm performance by country, year, firm size and location size

\begin{tabular}{|c|c|c|c|c|c|c|c|c|}
\hline & \multicolumn{3}{|c|}{ BEEPS } & \multicolumn{5}{|c|}{ BEEPS-Amadeus } \\
\hline & $\begin{array}{l}\mathrm{N} \text {, freq. } \\
\text { distr. }\end{array}$ & $\begin{array}{c}\text { Bribery } \\
\text { Level }\end{array}$ & $\begin{array}{c}\text { Bribery } \\
\text { Dispersion }\end{array}$ & $\begin{array}{l}\mathrm{N} \text {, freq. } \\
\text { distr. }\end{array}$ & $\begin{array}{c}\text { Bribery } \\
\text { Level }\end{array}$ & $\begin{array}{c}\text { Bribery } \\
\text { Dispersion }\end{array}$ & $\begin{array}{c}\text { Sales } \\
\text { Growth }\end{array}$ & $\begin{array}{c}\text { Lab. prod. } \\
\text { Growth }\end{array}$ \\
\hline \multicolumn{9}{|c|}{ Country } \\
\hline Slovenia & $4.1 \%$ & 0.12 & 0.18 & $0.8 \%$ & 0.13 & 0.18 & $16.0 \%$ & $8.1 \%$ \\
\hline Hungary & $8.2 \%$ & 0.17 & 0.20 & $1.9 \%$ & 0.15 & 0.18 & $1.3 \%$ & $-2.9 \%$ \\
\hline Poland & $15.4 \%$ & 0.20 & 0.22 & $3.9 \%$ & 0.17 & 0.21 & $6.8 \%$ & $4.5 \%$ \\
\hline Czech Rep. & $5.2 \%$ & 0.20 & 0.21 & $4.8 \%$ & 0.18 & 0.18 & $4.6 \%$ & $-0.9 \%$ \\
\hline Slovakia & $3.4 \%$ & 0.24 & 0.21 & $0.6 \%$ & 0.23 & 0.21 & $14.3 \%$ & $-4.1 \%$ \\
\hline Estonia & $3.5 \%$ & 0.12 & 0.17 & $1.9 \%$ & 0.15 & 0.19 & $7.1 \%$ & $4.3 \%$ \\
\hline Latvia & $3.6 \%$ & 0.18 & 0.22 & $0.8 \%$ & 0.19 & 0.24 & $12.1 \%$ & $1.2 \%$ \\
\hline Lithuania & $3.9 \%$ & 0.22 & 0.23 & $0.9 \%$ & 0.20 & 0.21 & $17.5 \%$ & $10.0 \%$ \\
\hline Bulgaria & $5.3 \%$ & 0.25 & 0.24 & $5.0 \%$ & 0.29 & 0.25 & $9.2 \%$ & $1.5 \%$ \\
\hline Romania & $10.5 \%$ & 0.27 & 0.27 & $19.8 \%$ & 0.28 & 0.27 & $6.1 \%$ & $-0.3 \%$ \\
\hline Croatia & $2.8 \%$ & 0.21 & 0.23 & $2.7 \%$ & 0.22 & 0.25 & $6.4 \%$ & $-1.0 \%$ \\
\hline Serbia & $5.0 \%$ & 0.31 & 0.25 & $3.0 \%$ & 0.34 & 0.25 & $8.0 \%$ & $2.3 \%$ \\
\hline Russia & $15.5 \%$ & 0.38 & 0.29 & $32.1 \%$ & 0.38 & 0.29 & $4.0 \%$ & $-11.3 \%$ \\
\hline Ukraine & $13.8 \%$ & 0.32 & 0.29 & $21.8 \%$ & 0.34 & 0.29 & $0.8 \%$ & $1.5 \%$ \\
\hline \multicolumn{9}{|c|}{ Time period } \\
\hline 1999-2001 & $21.1 \%$ & 0.32 & 0.27 & $12.3 \%$ & 0.37 & 0.29 & $8.1 \%$ & $3.4 \%$ \\
\hline 2002-2004 & $38.0 \%$ & 0.25 & 0.25 & $39.7 \%$ & 0.33 & 0.28 & $7.0 \%$ & $1.0 \%$ \\
\hline 2005-2007 & $41.0 \%$ & 0.22 & 0.23 & $47.9 \%$ & 0.27 & 0.25 & $1.9 \%$ & $-7.8 \%$ \\
\hline \multicolumn{9}{|c|}{ Firm size } \\
\hline 2-10 empl & $37.9 \%$ & 0.25 & 0.25 & $46.0 \%$ & 0.29 & 0.27 & $2.4 \%$ & $-3.3 \%$ \\
\hline 11-49 empl & $29.7 \%$ & 0.26 & 0.25 & $36.7 \%$ & 0.32 & 0.27 & $7.8 \%$ & $-4.1 \%$ \\
\hline $50+$ empl & $32.4 \%$ & 0.25 & 0.24 & $17.3 \%$ & 0.34 & 0.26 & $3.9 \%$ & $0.3 \%$ \\
\hline \multicolumn{9}{|c|}{ Location size } \\
\hline Capital & $18.3 \%$ & 0.28 & 0.24 & $12.8 \%$ & 0.34 & 0.26 & $6.8 \%$ & $-4.6 \%$ \\
\hline Over 1 mil & $5.1 \%$ & 0.39 & 0.31 & $5.2 \%$ & 0.40 & 0.34 & $7.2 \%$ & $-7.8 \%$ \\
\hline Below 1 mil & $76.6 \%$ & 0.24 & 0.24 & $82.0 \%$ & 0.30 & 0.26 & $4.2 \%$ & $-2.4 \%$ \\
\hline Total & 10093 & 0.25 & 0.24 & 701894 & 0.31 & 0.27 & $4.7 \%$ & $-3.0 \%$ \\
\hline
\end{tabular}

Note: Table reports frequency distribution of the number of observations, bribery measures and firm performance by country, year, firm size and location size for the BEEPS and BEEPS-Amadeus datasets. Bribery Level and Bribery Dispersion are the means and standard deviations of the bribery measure from the BEEPS within country-time period-industry-firm size-location size cells respectively. The last row reports the total number of observations, and overall averages of corresponding variables. The BEEPS-Amadeus dataset is reduced to three time periods corresponding to the three BEEPS waves. 


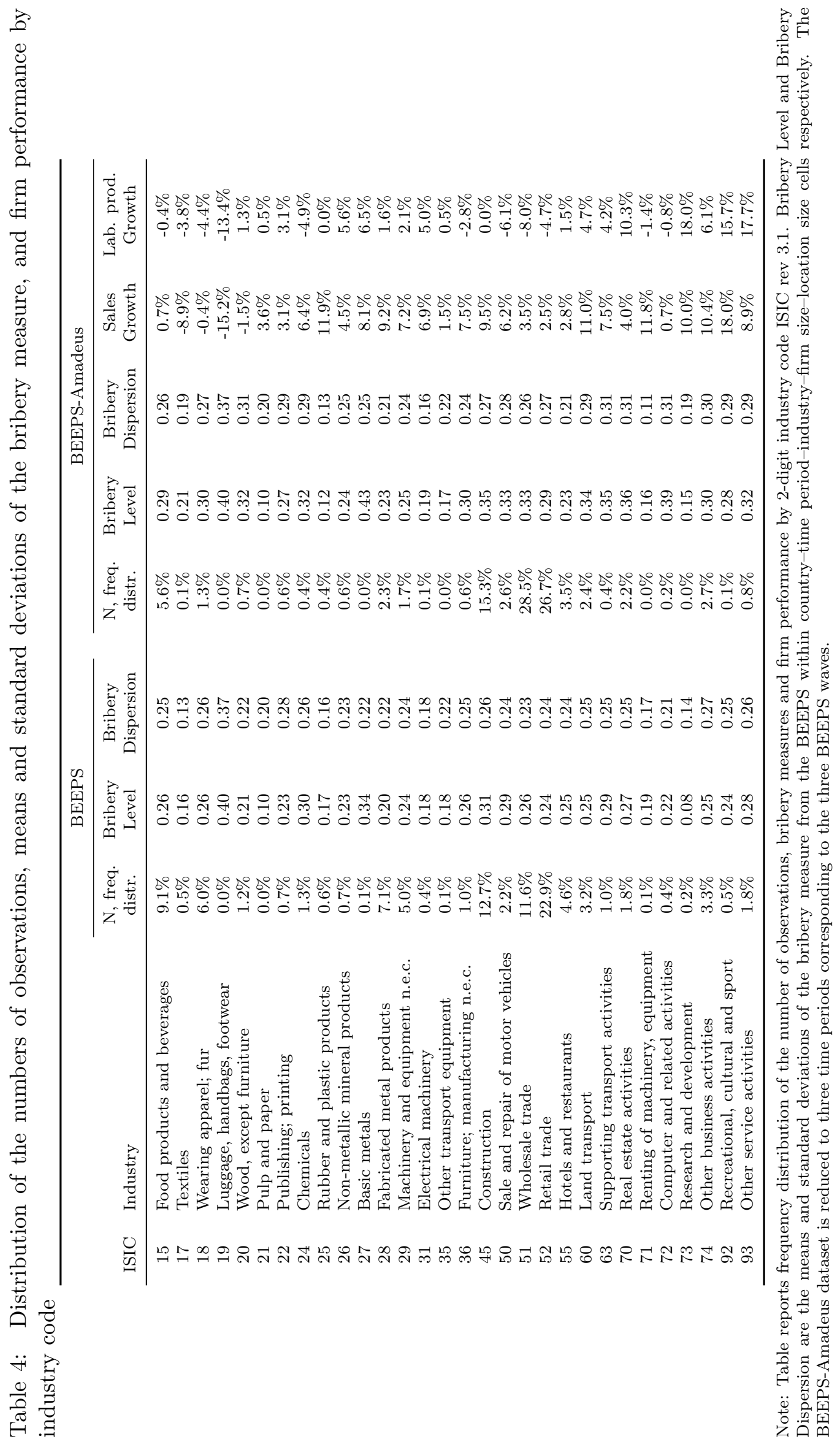




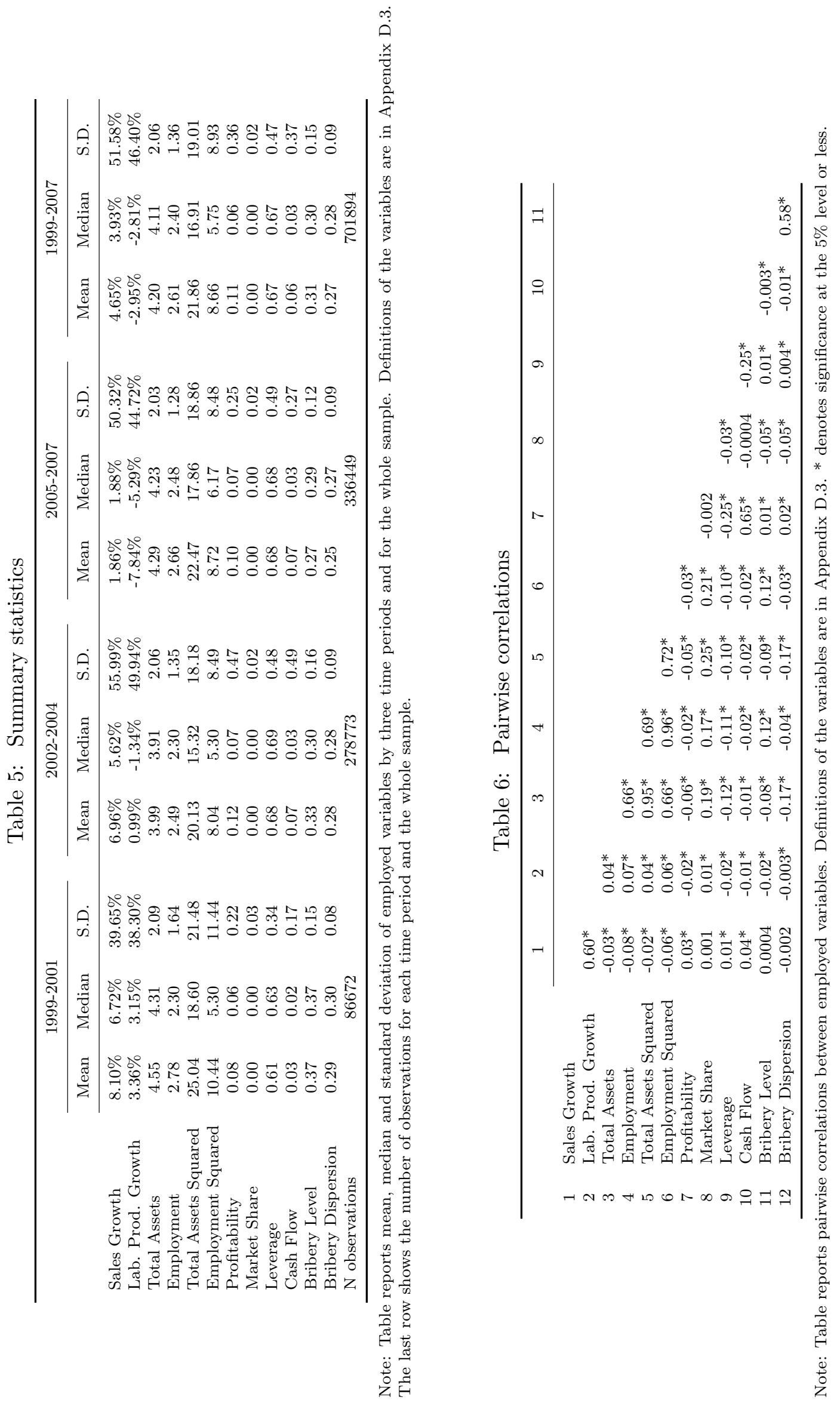




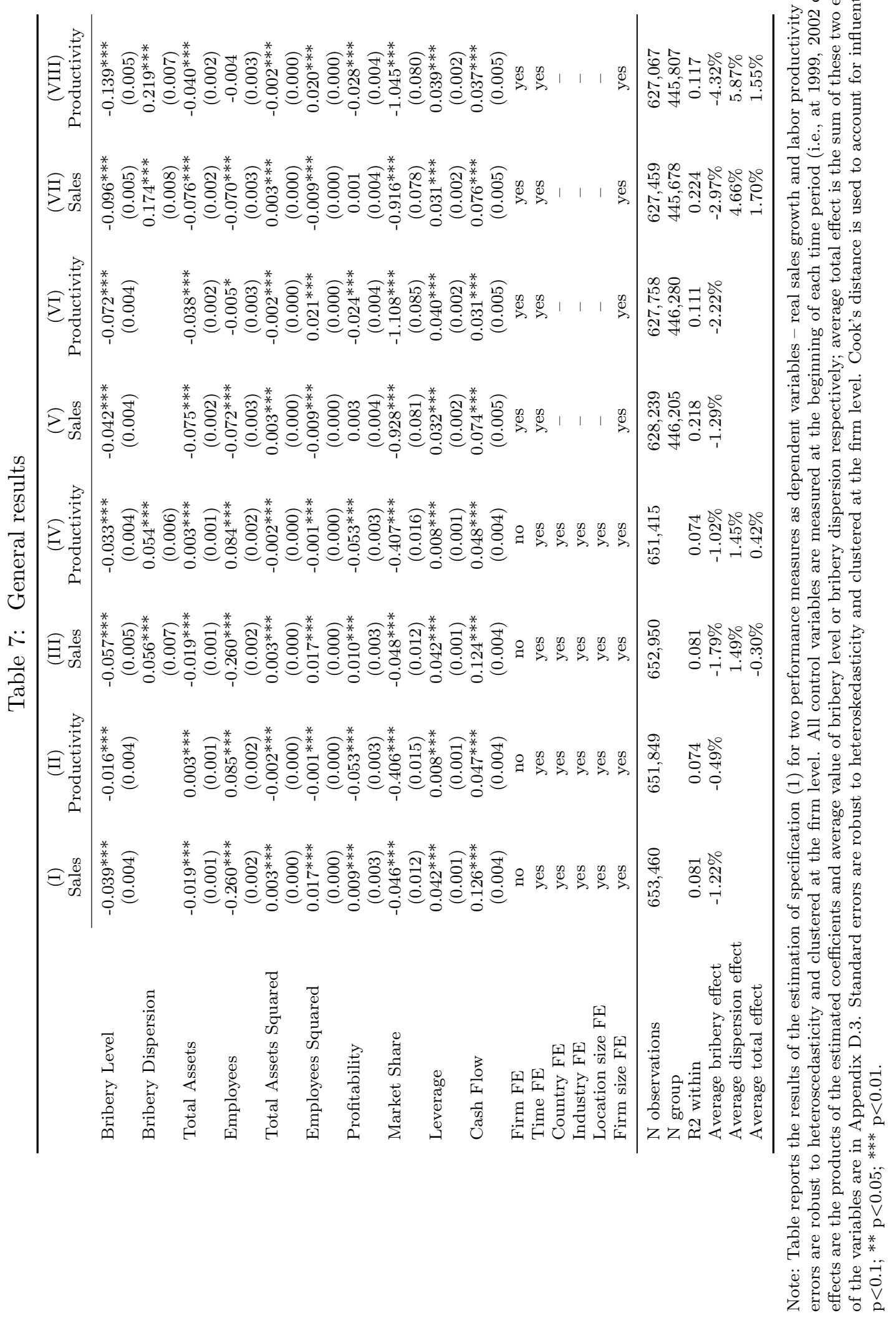


Table 8: Results for different types of firms

\begin{tabular}{|c|c|c|c|c|c|c|}
\hline & $\begin{array}{c}(\mathrm{I}) \\
\text { Sales }\end{array}$ & $\begin{array}{c}(\mathrm{II}) \\
\text { Productivity }\end{array}$ & $\begin{array}{l}\text { (III) } \\
\text { Sales }\end{array}$ & $\begin{array}{c}(\mathrm{IV}) \\
\text { Productivity }\end{array}$ & $\begin{array}{l}(\mathrm{V}) \\
\text { Sales }\end{array}$ & $\begin{array}{c}(\mathrm{VI}) \\
\text { Productivity }\end{array}$ \\
\hline & \multicolumn{6}{|c|}{ Panel A: Manufacturing and service firms } \\
\hline & \multicolumn{2}{|c|}{ Manufacturing } & \multicolumn{2}{|c|}{ Services } & \multicolumn{2}{|c|}{$\begin{array}{l}\text { Services } \mathrm{w} / \mathrm{o} \text { wholesale } \\
\text { and retail trade }\end{array}$} \\
\hline Bribery Level & $\begin{array}{c}-0.258^{* * *} \\
(0.010)\end{array}$ & $\begin{array}{c}-0.146^{* * *} \\
(0.010)\end{array}$ & $\begin{array}{c}-0.035^{* * *} \\
(0.006)\end{array}$ & $\begin{array}{c}-0.115^{* * *} \\
(0.006)\end{array}$ & $\begin{array}{c}0.001 \\
(0.009)\end{array}$ & $\begin{array}{c}0.161^{* * *} \\
(0.010)\end{array}$ \\
\hline Bribery Dispersion & $\begin{array}{l}-0.027 \\
(0.017)\end{array}$ & $\begin{array}{c}-0.094^{* * * *} \\
(0.017)\end{array}$ & $\begin{array}{c}0.136^{* * *} \\
(0.009)\end{array}$ & $\begin{array}{c}0.234^{* * *} \\
(0.009)\end{array}$ & $\begin{array}{c}-0.058^{* * *} \\
(0.015)\end{array}$ & $\begin{array}{c}-0.090 * * * \\
(0.017)\end{array}$ \\
\hline Controls not reported & & & & & & \\
\hline $\mathrm{N}$ observations & 88917 & 88960 & 442567 & 441964 & 92658 & 92174 \\
\hline N group & 68456 & 68475 & 311164 & 311008 & 76603 & 76368 \\
\hline R2 within & 0.362 & 0.201 & 0.231 & 0.124 & 0.342 & 0.253 \\
\hline Average bribery effect & $-6.99 \%$ & $-3.95 \%$ & $-1.08 \%$ & $-3.57 \%$ & $0.03 \%$ & $5.00 \%$ \\
\hline Average dispersion effect & $-0.68 \%$ & $-2.37 \%$ & $3.65 \%$ & $6.30 \%$ & $-1.55 \%$ & $-2.41 \%$ \\
\hline \multirow[t]{3}{*}{ Average total effect } & $-7.67 \%$ & $-6.32 \%$ & $2.57 \%$ & $2.73 \%$ & $-1.52 \%$ & $2.59 \%$ \\
\hline & \multicolumn{6}{|c|}{ Panel B: Construction and service firms } \\
\hline & \multicolumn{2}{|c|}{ Construction } & \multicolumn{2}{|c|}{ Wholesale trade } & \multicolumn{2}{|c|}{ Retail trade } \\
\hline Bribery Level & $\begin{array}{c}-0.107 * * * \\
(0.013)\end{array}$ & $\begin{array}{c}-0.145^{* * *} \\
(0.012)\end{array}$ & $\begin{array}{c}-0.115^{* * *} \\
(0.014)\end{array}$ & $\begin{array}{c}-0.178^{* * *} \\
(0.013)\end{array}$ & $\begin{array}{c}-0.144^{* * *} \\
(0.010)\end{array}$ & $\begin{array}{c}-0.323^{* * *} \\
(0.012)\end{array}$ \\
\hline Bribery Dispersion & $\begin{array}{c}0.381^{* * *} \\
(0.020)\end{array}$ & $\begin{array}{c}0.285^{* * *} \\
(0.017)\end{array}$ & $\begin{array}{c}0.242^{* * *} \\
(0.018)\end{array}$ & $\begin{array}{c}0.302^{* * *} \\
(0.016)\end{array}$ & $\begin{array}{c}0.183^{* * *} \\
(0.015)\end{array}$ & $\begin{array}{c}0.396^{* * * *} \\
(0.016)\end{array}$ \\
\hline Controls not reported & & & & & & \\
\hline $\mathrm{N}$ observations & 96137 & 96402 & 177475 & 176808 & 170735 & 171817 \\
\hline N group & 65960 & 66195 & 134149 & 133939 & 99572 & 99948 \\
\hline R2 within & 0.176 & 0.081 & 0.270 & 0.109 & 0.201 & 0.129 \\
\hline Average bribery effect & $-3.74 \%$ & $-5.05 \%$ & $-3.82 \%$ & $-5.91 \%$ & $-4.15 \%$ & $-9.30 \%$ \\
\hline Average dispersion effect & $10.42 \%$ & $7.79 \%$ & $6.41 \%$ & $8.00 \%$ & $4.97 \%$ & $10.75 \%$ \\
\hline Average total effect & $6.68 \%$ & $2.74 \%$ & $2.59 \%$ & $2.10 \%$ & $0.82 \%$ & $1.45 \%$ \\
\hline
\end{tabular}

Note: Table reports the results of the estimation of specification (1) for different subsamples of firms for two performance measures as dependent variables - real sales growth and labor productivity growth. In Panel A firms are divided into subsamples of manufacturing (ISIC code 15-36), services (ISIC code 51-93) and services excluding wholesale and retail trade sectors (ISIC code 51,52). In panel B firms are divided into subsamples of construction (ISIC code 45), retail trade (ISIC code 51) and wholesale trade (ISIC code 52) sectors. All control variables are measured at the beginning of each time period (i.e., at 1999, 2002 or 2005). Average effects are the products of the estimated coefficients and average value of bribery level or bribery dispersion respectively; average total effect is the sum of these two effects. Definitions of the variables are in Appendix D.3. Standard errors are robust to heteroskedasticity and clustered at the firm level. Cook's distance is used to account for influential observation. * $\mathrm{p}<0.1 ;{ }^{* *} \mathrm{p}<0.05 ;{ }^{* * *} \mathrm{p}<0.01$. 
Table 9: Results for different types of firms

\begin{tabular}{|c|c|c|c|c|c|c|}
\hline & $\begin{array}{c}(\mathrm{I}) \\
\text { Sales }\end{array}$ & $\begin{array}{c}(\mathrm{II}) \\
\text { Productivity }\end{array}$ & $\begin{array}{l}\text { (III) } \\
\text { Sales }\end{array}$ & $\begin{array}{c}(\mathrm{IV}) \\
\text { Productivity }\end{array}$ & $\begin{array}{c}(\mathrm{V}) \\
\text { Sales }\end{array}$ & $\begin{array}{c}(\mathrm{VI}) \\
\text { Productivity }\end{array}$ \\
\hline & \multicolumn{6}{|c|}{ Panel A: Micro, small and large firms } \\
\hline & \multicolumn{2}{|c|}{ 2-10 employees } & \multicolumn{2}{|c|}{ 11-49 employees } & \multicolumn{2}{|c|}{$50+$ employees } \\
\hline Bribery Level & $\begin{array}{c}-0.026^{* * *} \\
(0.008)\end{array}$ & $\begin{array}{c}-0.095^{* * * *} \\
(0.009)\end{array}$ & $\begin{array}{c}-0.118^{* * *} \\
(0.011)\end{array}$ & $\begin{array}{c}-0.118^{* * * *} \\
(0.010)\end{array}$ & $\begin{array}{c}-0.201^{* * *} \\
(0.010)\end{array}$ & $\begin{array}{c}-0.150^{* * * *} \\
(0.010)\end{array}$ \\
\hline Bribery Dispersion & $\begin{array}{l}0.032^{*} \\
(0.018)\end{array}$ & $\begin{array}{c}0.104^{* * *} \\
(0.019)\end{array}$ & $\begin{array}{c}0.284^{* * *} * \\
(0.013)\end{array}$ & $\begin{array}{c}0.271^{* * *} * \\
(0.011)\end{array}$ & $\begin{array}{c}0.159^{* * *} \\
(0.015)\end{array}$ & $\begin{array}{c}0.148^{* * *} \\
(0.014)\end{array}$ \\
\hline Controls not reported & & & & & & \\
\hline $\mathrm{N}$ observations & 291283 & 291513 & 228848 & 228688 & 107719 & 107728 \\
\hline $\mathrm{N}$ group & 218455 & 219066 & 179598 & 179491 & 76147 & 76463 \\
\hline R2 within & 0.207 & 0.104 & 0.247 & 0.124 & 0.238 & 0.097 \\
\hline Average bribery effect & $-0.76 \%$ & $-2.79 \%$ & $-3.80 \%$ & $-3.79 \%$ & $-6.78 \%$ & $-5.04 \%$ \\
\hline Average dispersion effect & $0.87 \%$ & $2.83 \%$ & $7.55 \%$ & $7.20 \%$ & $4.11 \%$ & $3.83 \%$ \\
\hline \multirow[t]{3}{*}{ Average total effect } & $0.11 \%$ & $0.04 \%$ & $3.74 \%$ & $3.41 \%$ & $-2.67 \%$ & $-1.21 \%$ \\
\hline & \multicolumn{6}{|c|}{ Panel B: Stable, new entrants and exited firms } \\
\hline & \multicolumn{2}{|c|}{ Stable } & \multicolumn{2}{|c|}{ New entrants } & \multicolumn{2}{|c|}{ Exited } \\
\hline Bribery Level & $\begin{array}{c}-0.151^{* * *} \\
(0.008)\end{array}$ & $\begin{array}{c}-0.097^{* * *} \\
(0.009)\end{array}$ & $\begin{array}{c}-0.098^{* * * *} \\
(0.009)\end{array}$ & $\begin{array}{c}-0.177^{* * *} \\
(0.008)\end{array}$ & $\begin{array}{c}-0.290^{* * *} \\
(0.020)\end{array}$ & $\begin{array}{c}-0.168^{* * *} \\
(0.021)\end{array}$ \\
\hline Bribery Dispersion & $\begin{array}{c}0.151^{* * *} * \\
(0.013)\end{array}$ & $\begin{array}{c}0.098^{* * *} \\
(0.014)\end{array}$ & $\begin{array}{c}0.222^{* * *} * \\
(0.013)\end{array}$ & $\begin{array}{c}0.235^{* * *} \\
(0.011)\end{array}$ & $\begin{array}{c}0.219^{* * *} \\
(0.045)\end{array}$ & $\begin{array}{c}0.414^{* * *} \\
(0.047)\end{array}$ \\
\hline Controls not reported & & & & & & \\
\hline $\mathrm{N}$ observations & 101841 & 101859 & 212722 & 213066 & 28004 & 28072 \\
\hline $\mathrm{N}$ group & 33947 & 33953 & 106361 & 106533 & 14002 & 14036 \\
\hline R2 within & 0.198 & 0.147 & 0.196 & 0.093 & 0.118 & 0.101 \\
\hline Average bribery effect & $-4.36 \%$ & $-2.79 \%$ & $-2.93 \%$ & $-5.29 \%$ & $-9.69 \%$ & $-5.63 \%$ \\
\hline Average dispersion effect & $4.01 \%$ & $2.60 \%$ & $5.74 \%$ & $6.07 \%$ & $6.20 \%$ & $11.73 \%$ \\
\hline Average total effect & $-0.35 \%$ & $-0.19 \%$ & $2.80 \%$ & $0.77 \%$ & $-3.49 \%$ & $6.10 \%$ \\
\hline
\end{tabular}

Note: Table reports the results of the estimation of specification (1) for different subsamples of firms for two performance measures as dependent variables - real sales growth and labor productivity growth. In panel A firms are divided into subsamples of micro (2-10 employees), small (11-49 employees) and medium and large (more than 50 employees) firms. In Panel B firms are divided into subsamples of stable (present in the sample during all three time periods), new entrant (present in the sample in the second and third periods), and exited (present in the sample in the first and second periods) firms. All control variables are measured the beginning of each time period (i.e., at 1999, 2002 or 2005). Average effects are the products of the estimated coefficients and average value of bribery level or bribery dispersion respectively; average total effect is the sum of these two effects. Definitions of the variables are in Appendix D.3. Standard errors are robust to heteroskedasticity and clustered at the firm level. Cook's distance is used to account for influential observation. ${ }^{*} \mathrm{p}<0.1 ;{ }^{* *} \mathrm{p}<0.05 ;{ }^{* * *} \mathrm{p}<0.01$. 
Table 10: Country institutions and impact of bribery

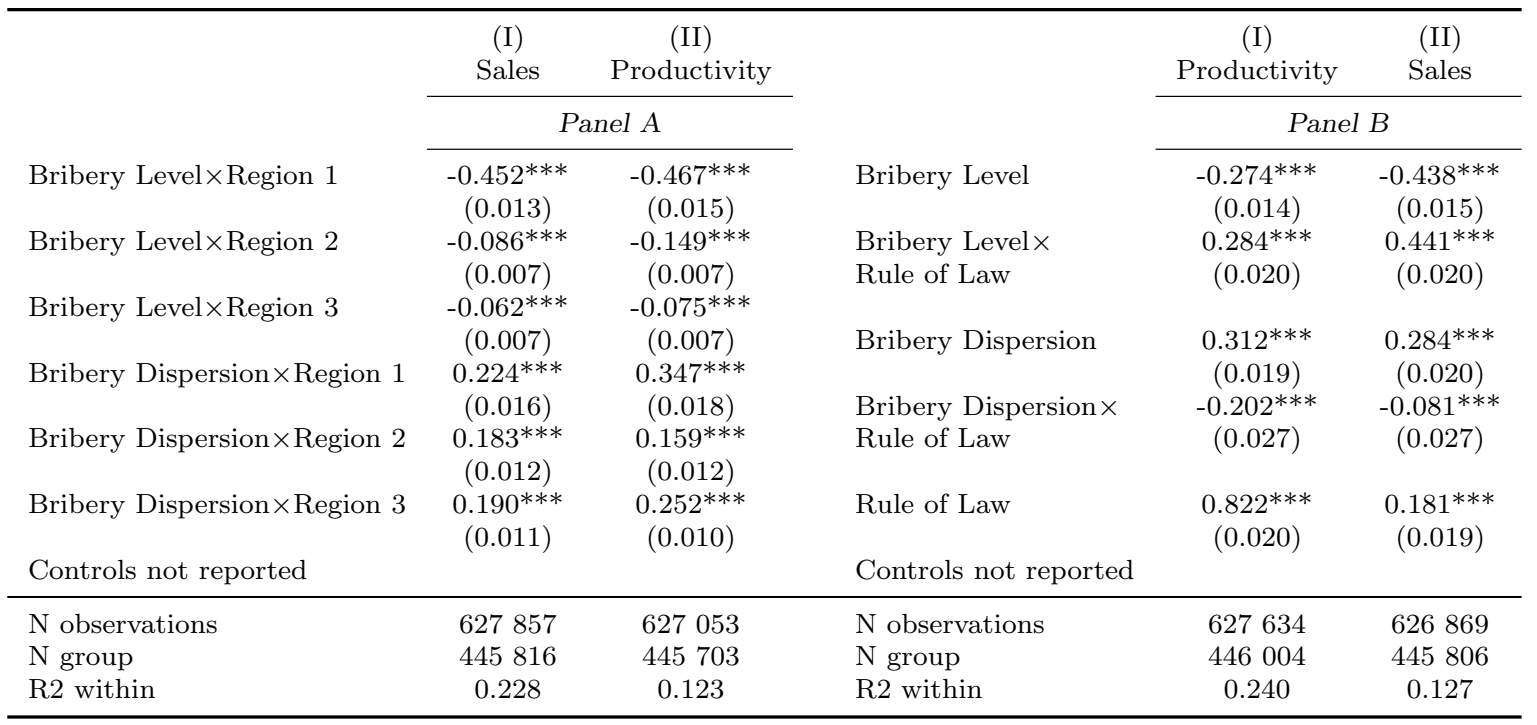

Note: Table reports the results of the estimation of modified specification (1) for two performance measures as dependent variables - real sales growth and labor productivity growth. In Panel A the coefficients on Bribe and Bribe Dispersion vary for three regions: Region 1 - Slovenia, Hungary, Poland, Czech Republic, Slovakia, Estonia, Latvia and Lithuania; Region 2 - Croatia, Serbia, Bulgaria and Romania; and Region 3 - Russia and Ukraine. In Panel B interactions between Bribery Level and Rule of Law, and between Bribery Dispersion and Rule of Law as well as the Rule of Law indicator are included into specification (1). The Rule of Law indicator varies from 0 to 1 , where higher values stand for weaker institutions. All control variables are measured at the beginning of each time period (i.e., at 1999, 2002 or 2005). Definitions of the variables are in Appendix D.3. Standard errors are robust to heteroskedasticity and clustered at the firm level. Cook's distance is used to account for influential observation. * $\mathrm{p}<0.1 ; * * \mathrm{p}<0.05 ; * * * \mathrm{p}<0.01$.

Table 11: Local environments and impact of bribery

\begin{tabular}{|c|c|c|c|c|}
\hline & $\begin{array}{c}(\mathrm{I}) \\
\text { Sales }\end{array}$ & $\begin{array}{c}\text { (II) } \\
\text { Productivity }\end{array}$ & $\begin{array}{l}\text { (III) } \\
\text { Sales }\end{array}$ & $\begin{array}{c}\text { (IV) } \\
\text { Productivity }\end{array}$ \\
\hline Bribery Level $\times$ Even Environment & $\begin{array}{c}-0.053^{* * *} \\
(0.004)\end{array}$ & $\begin{array}{c}-0.067^{* * *} \\
(0.004)\end{array}$ & & \\
\hline Bribery Level $\times$ Uneven Environment & $\begin{array}{c}0.029 * * * \\
(0.003)\end{array}$ & $\begin{array}{c}0.012^{* * *} \\
(0.003)\end{array}$ & & \\
\hline Uneven Environment & & & $\begin{array}{c}0.010^{* * *} \\
(0.001)\end{array}$ & $\begin{array}{c}0.011^{* * *} \\
(0.001)\end{array}$ \\
\hline Low Bribery Level $\times$ Even Environment & & & $\begin{array}{c}-0.011^{* * *} \\
(0.002)\end{array}$ & $\begin{array}{c}0.006^{* * *} \\
(0.002)\end{array}$ \\
\hline High Bribery Level $\times$ Even Environment & & & $\begin{array}{c}-0.062^{* * *} \\
(0.002)\end{array}$ & $\begin{array}{c}-0.036^{* * *} \\
(0.002)\end{array}$ \\
\hline \multicolumn{5}{|l|}{ Controls not reported } \\
\hline $\mathrm{N}$ observations & 627446 & 627191 & 627098 & 626858 \\
\hline N group & 445786 & 446027 & 445627 & 445787 \\
\hline R2 within & 0.221 & 0.111 & 0.223 & 0.114 \\
\hline
\end{tabular}

Note: Table reports the results of the estimation of modified specification (1) for two performance measures as dependent variables - real sales growth and labor productivity growth. Even (uneven) environment is equal to one if Bribery Dispersion is less than or equal to the 25th percentile (greater than or equal to the 75th percentile) of its distribution for each country. Low (High) Bribery Level is equal to one if Bribery Level is less than or equal to the 25 th percentile (greater than or equal to the 75 th percentile) of its distribution. All control variables are measured at the beginning of each time period (i.e., at 1999, 2002 or 2005). Definitions of the variables are in Appendix D.3. Standard errors are robust to heteroskedasticity and clustered at the firm level. Cook's distance is used to account for influential observation. ${ }^{*} \mathrm{p}<0.1 ; * * \mathrm{p}<0.05 ; * * * \mathrm{p}<0.01$. 
Table 12: Robustness check

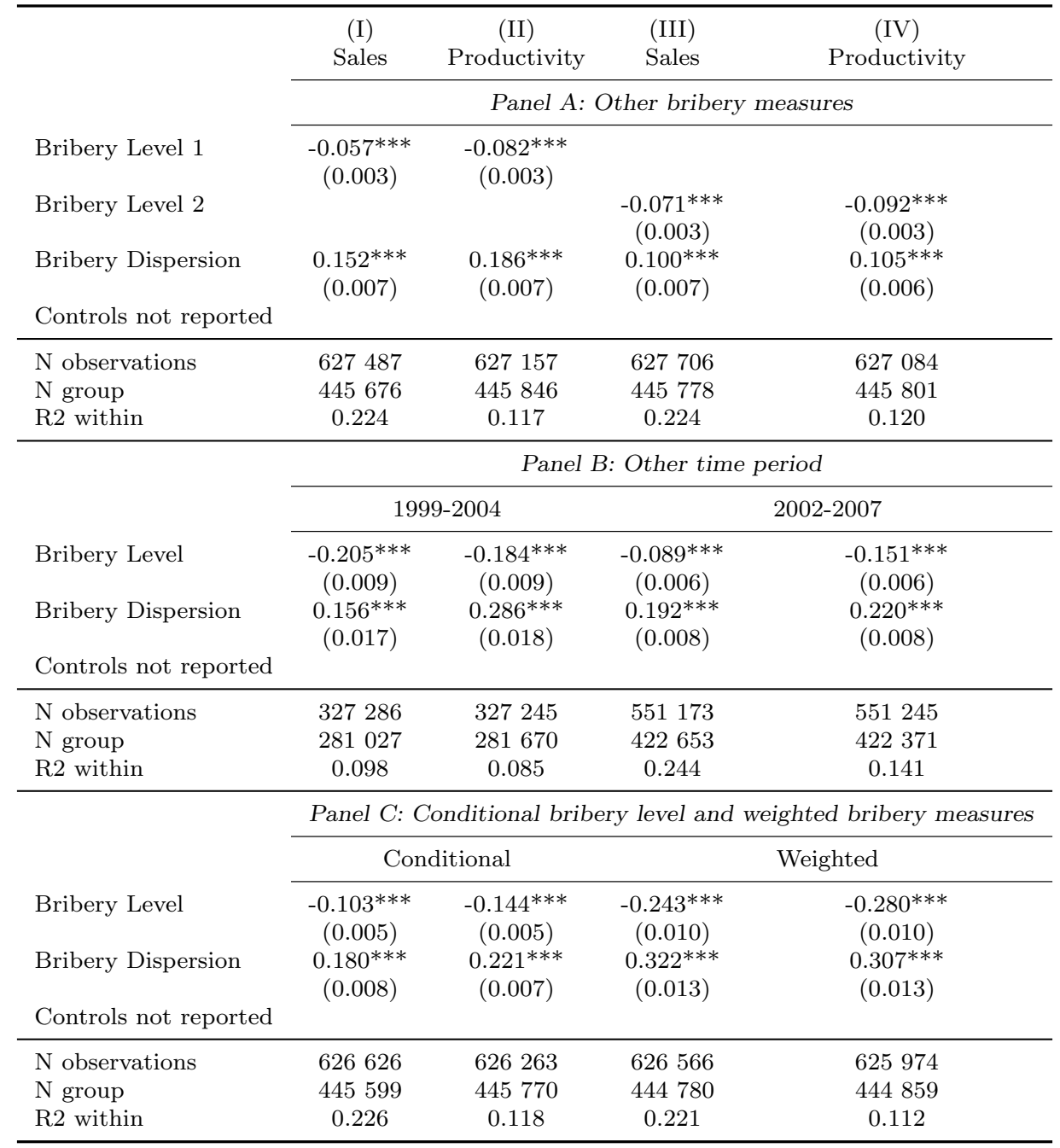

Note: Table reports the results of the estimation of specification (1) for two performance measures as dependent variables - real sales growth and labor productivity growth. In Panel A two other measures on the bribery level are used. Bribery Level 1 is computed from the dummy variable that takes value one if firms report that they bribe public officials sometimes, frequently, usually and always to 'get things done,' and zero otherwise; Bribery Level 2 is computed from the dummy variable that takes value one if firms report that they bribe seldom, sometimes, frequently, usually and always, and zero if never. Columns I-IV, Panel B present the results for two time periods separately. In columns I-II, Panel C, Bribery Level variable is computed as the mean of the bribery measure from the BEEPS but conditional on firm characteristics such as the dummy variables for foreign ownership and exporter status, and the logarithm of firm age. In columns III-IV, Panel C, Bribery Level and Dispersion variables are reweighted to account for composition of young and old firms within cells in Amadeus. All control variables are measured at the beginning of each time period (i.e., at 1999, 2002 or 2005). Definitions of the variables are in Appendix D.3. Standard errors are robust to heteroskedasticity and clustered at the firm level. Cook's distance is used to account for influential observation. ${ }^{*} \mathrm{p}<0.1 ; * * \mathrm{p}<0.05 ; * * * \mathrm{p}<0.01$. 
Table 13: Robustness check

\begin{tabular}{|c|c|c|c|c|}
\hline & $\begin{array}{c}(\mathrm{I}) \\
\text { Sales }\end{array}$ & $\begin{array}{c}(\mathrm{II}) \\
\text { Productivity }\end{array}$ & $\begin{array}{l}(\mathrm{III}) \\
\text { Sales }\end{array}$ & $\begin{array}{c}(\mathrm{IV}) \\
\text { Productivity }\end{array}$ \\
\hline & \multicolumn{4}{|c|}{ Panel A: Other data structure and method of estimation } \\
\hline & \multicolumn{2}{|c|}{ Firm and year FE } & \multicolumn{2}{|c|}{ Arrelano-Bond } \\
\hline Bribery Level & $\begin{array}{c}-0.085^{* * *} \\
(0.005)\end{array}$ & $\begin{array}{c}-0.088^{* * *} \\
(0.005)\end{array}$ & $\begin{array}{c}-0.100 * * * \\
(0.011)\end{array}$ & $\begin{array}{c}-0.109 * * * \\
(0.012)\end{array}$ \\
\hline Bribery Dispersion & $\begin{array}{c}0.138^{* * *} \\
(0.007)\end{array}$ & $\begin{array}{c}0.157^{* * *} \\
(0.007)\end{array}$ & $\begin{array}{c}0.134^{* * *} \\
(0.018)\end{array}$ & $\begin{array}{c}0.047^{* * *} \\
(0.018)\end{array}$ \\
\hline Sales/Lab. prod. growth ${ }_{t-1}$ & & & $\begin{array}{c}-0.016 * * * \\
(0.003)\end{array}$ & $\begin{array}{c}-0.059 * * * \\
(0.002)\end{array}$ \\
\hline \multicolumn{5}{|l|}{ Controls not reported } \\
\hline $\mathrm{N}$ observations & 1276553 & 1271603 & 676877 & 676877 \\
\hline $\mathrm{N}$ group & 455427 & 455661 & 262300 & 262300 \\
\hline $\mathrm{R} 2$ within & 0.143 & 0.192 & & \\
\hline $\mathrm{N}$ instruments & & & 74 & 74 \\
\hline A-B test for $\mathrm{AR}(1) / \mathrm{p}$-value & & & $-97.58 / 0.00$ & $-118.91 / 0.00$ \\
\hline \multirow[t]{3}{*}{ A-B test for $\mathrm{AR}(2) / \mathrm{p}$-value } & & & $0.80 / 0.42$ & $-0.94 / 0.347$ \\
\hline & \multicolumn{4}{|c|}{ Panel B: Different number observations in a cell } \\
\hline & \multicolumn{2}{|c|}{$\mathrm{N}$ obs. in a cell $3+$} & \multicolumn{2}{|c|}{$\mathrm{N}$ obs. in a cell $5+$} \\
\hline Bribery Level & $\begin{array}{c}-0.058^{* * *} \\
(0.004)\end{array}$ & $\begin{array}{c}-0.095^{* * *} \\
(0.004)\end{array}$ & $\begin{array}{c}-0.131^{* * *} \\
(0.006)\end{array}$ & $\begin{array}{c}-0.161^{* * *} \\
(0.006)\end{array}$ \\
\hline Bribery Dispersion & $\begin{array}{c}0.083^{* * * *} \\
(0.006)\end{array}$ & $\begin{array}{c}0.073^{* * *} \\
(0.006)\end{array}$ & $\begin{array}{c}0.242^{* * * *} \\
(0.011)\end{array}$ & $\begin{array}{c}0.280^{* * * *} \\
(0.010)\end{array}$ \\
\hline Controls not reported & & & & \\
\hline $\mathrm{N}$ observations & 739280 & 740722 & 552053 & 552877 \\
\hline $\mathrm{N}$ group & 506834 & 508011 & 397446 & 398761 \\
\hline R2 within & 0.196 & 0.101 & 0.208 & 0.112 \\
\hline
\end{tabular}

Note: Table reports the results of the estimation of specification (1) for two performance measures as dependent variables - real sales growth and labor productivity growth. In Panel A yearly firm-level data is used, control variables are lagged one year back. The estimates in columns I-II are obtained using conventional firm, firm size, and time fixed effects estimation. The estimates in columns III-IV are obtained using Arellano and Bond's (1991) dynamic panel data estimation technique. Panel B presents the results for the datasets, when no fewer than 3 observations (columns I-II) and no fewer than 5 observations (columns III-IV) are kept in a country-time periodindustry-firm size-location size cell. In Panel B control variables are measured at the beginning of each time period (i.e., at 1999, 2002 or 2005). Definitions of the variables are in Appendix D.3. Standard errors are robust to heteroskedasticity and clustered at the firm level. Cook's distance is used to account for influential observation (not in columns III-IV, Panel A). ${ }^{*} \mathrm{p}<0.1 ;{ }^{* *} \mathrm{p}<0.05 ;{ }^{* * *} \mathrm{p}<0.01$. 
Table 14: Robustness check

\begin{tabular}{|c|c|c|c|c|c|c|}
\hline & $\begin{array}{c}(\mathrm{I}) \\
\text { Sales }\end{array}$ & $\begin{array}{l}(\mathrm{II}) \\
\text { Productivity }\end{array}$ & $\begin{array}{l}(\mathrm{III}) \\
\text { Sales }\end{array}$ & $\begin{array}{l}(\mathrm{IV}) \\
\text { Productivity }\end{array}$ & $\begin{array}{l}(\mathrm{V}) \\
\text { Sales }\end{array}$ & $\begin{array}{l}(\mathrm{VI}) \\
\text { Productivity }\end{array}$ \\
\hline & \multicolumn{6}{|c|}{ Panel A: Firms in capitals, other merging criteria and weighted regressions } \\
\hline & \multicolumn{2}{|c|}{$\begin{array}{l}\text { Subsample of firms } \\
\text { located in capitals }\end{array}$} & \multicolumn{2}{|c|}{$\begin{array}{l}\text { Merging criteria } \\
\text { w/o location size }\end{array}$} & \multicolumn{2}{|c|}{ Weighted OLS } \\
\hline Bribery Level & $\begin{array}{c}-0.034^{* * *} \\
(0.005)\end{array}$ & $\begin{array}{c}-0.131^{* * *} \\
(0.019)\end{array}$ & $\begin{array}{c}-0.138^{* * *} \\
(0.005)\end{array}$ & $\begin{array}{c}-0.078 * * * \\
(0.005)\end{array}$ & $\begin{array}{c}-0.098 * * * \\
(0.005)\end{array}$ & $\begin{array}{c}-0.138^{* * *} \\
(0.005)\end{array}$ \\
\hline Bribery Dispersion & $\begin{array}{c}0.165^{* * *} \\
(0.022)\end{array}$ & $\begin{array}{c}0.102^{* * *} \\
(0.022)\end{array}$ & $\begin{array}{c}0.100 * * * \\
(0.008)\end{array}$ & $\begin{array}{c}0.157^{* * *} \\
(0.008)\end{array}$ & $\begin{array}{c}0.179^{* * * *} \\
(0.008)\end{array}$ & $\begin{array}{c}0.219^{* * *} \\
(0.007)\end{array}$ \\
\hline Controls not reported & & & & & & \\
\hline $\mathrm{N}$ observations & 79701 & 79568 & 868233 & 869682 & 627459 & 627067 \\
\hline $\mathrm{N}$ group & 65389 & 65349 & 584781 & 585773 & 445678 & 445807 \\
\hline \multirow[t]{3}{*}{ R2 within } & 0.250 & 0.054 & 0.180 & 0.092 & 0.223 & 0.117 \\
\hline & \multicolumn{6}{|c|}{ Panel B: Sensitivity to outliers and data imputation } \\
\hline & \multicolumn{2}{|c|}{ No Cook's distance } & \multicolumn{2}{|c|}{ Outliers $5 \%$ and $95 \%$} & \multicolumn{2}{|c|}{ No imputation } \\
\hline Bribery Level & $\begin{array}{c}-0.075^{* * *} \\
(0.008)\end{array}$ & $\begin{array}{c}-0.148 * * * \\
(0.008)\end{array}$ & $\begin{array}{c}-0.107^{* * *} \\
(0.008)\end{array}$ & $\begin{array}{c}-0.079^{* * *} \\
(0.007)\end{array}$ & $\begin{array}{c}-0.119 * * * \\
(0.008)\end{array}$ & $\begin{array}{c}-0.126^{* * *} \\
(0.007)\end{array}$ \\
\hline Bribery Dispersion & $\begin{array}{c}0.136^{* * *} \\
(0.013)\end{array}$ & $\begin{array}{c}0.198^{* * * *} \\
(0.012)\end{array}$ & $\begin{array}{c}0.274^{* * *} \\
(0.012)\end{array}$ & $\begin{array}{c}0.195^{* * *} \\
(0.011)\end{array}$ & $\begin{array}{c}0.248^{* * *} \\
(0.012)\end{array}$ & $\begin{array}{c}0.203^{* * *} \\
(0.011)\end{array}$ \\
\hline Controls not reported & & & & & & \\
\hline $\mathrm{N}$ observations & 678381 & 678381 & 157057 & 156485 & 309742 & 307334 \\
\hline $\mathrm{N}$ group & 464634 & 464634 & 144969 & 144772 & 274938 & 273268 \\
\hline \multirow[t]{3}{*}{ R2 within } & 0.133 & 0.065 & 0.448 & 0.149 & 0.364 & 0.130 \\
\hline & \multicolumn{6}{|c|}{ Panel C: Inclusion of obstacles } \\
\hline & \multicolumn{2}{|c|}{ Corruption } & \multicolumn{2}{|c|}{ Tax administration } & \multicolumn{2}{|c|}{ Licences and permits } \\
\hline Bribery Level & $\begin{array}{c}-0.064^{* * *} \\
(0.005)\end{array}$ & $\begin{array}{c}-0.114^{* * *} \\
(0.005)\end{array}$ & $\begin{array}{c}-0.075^{* * *} \\
(0.005)\end{array}$ & $\begin{array}{c}-0.150 * * * \\
(0.005)\end{array}$ & $\begin{array}{c}-0.082^{* * *} \\
(0.005)\end{array}$ & $\begin{array}{c}-0.130 * * * \\
(0.005)\end{array}$ \\
\hline Bribery Dispersion & $\begin{array}{c}0.180^{* * *} \\
(0.008)\end{array}$ & $\begin{array}{c}0.224^{* * *} \\
(0.007)\end{array}$ & $\begin{array}{c}0.155^{* * *} \\
(0.008)\end{array}$ & $\begin{array}{c}0.231^{* * *} \\
(0.007)\end{array}$ & $\begin{array}{c}0.171^{* * *} \\
(0.008)\end{array}$ & $\begin{array}{c}0.215^{* * *} \\
(0.007)\end{array}$ \\
\hline Obstacle & $\begin{array}{c}-0.062^{* * *} \\
(0.004)\end{array}$ & $\begin{array}{c}-0.049^{* * *} \\
(0.004)\end{array}$ & $\begin{array}{c}-0.072^{* * *} \\
(0.004)\end{array}$ & $\begin{array}{c}0.047^{* * * *} \\
(0.004)\end{array}$ & $\begin{array}{c}-0.119 * * * \\
(0.004)\end{array}$ & $\begin{array}{c}-0.090 * * * \\
(0.004)\end{array}$ \\
\hline Controls not reported & & & & & & \\
\hline $\mathrm{N}$ observations & 627181 & 626526 & 627253 & 626910 & 627276 & 626526 \\
\hline $\mathrm{N}$ group & 445548 & 445542 & 445632 & 445804 & 445601 & 445673 \\
\hline R2 within & 0.228 & 0.120 & 0.229 & 0.120 & 0.228 & 0.120 \\
\hline
\end{tabular}

Note: Table reports the results of the estimation of specification (1) for two performance measures as dependent variables - real sales growth and labor productivity growth. In columns I-II, Panel A the sample is restricted to firms located in capitals of the countries. In columns III-IV, Panel A location size is omitted from the merging criteria of combining the BEEPS and the Amadeus databases. Columns V-VI, Panel A present the results from weighted regressions with weights equal to the ratios of the number of non-missing (in the original bribery measure from the BEEPS) observations to the total number of observations in cells. In columns I-II, Panel B Cook's square distance is not used, in columns III-IV, Panel B an other definition of severe outliers is used; in columns V-VI, Panel B the dataset without imputation is used. Panel $\mathrm{C}$ presents the results with additional variables included: corruption, tax administration, and obtaining business licences and permits respectively. All control variables are measured at the beginning of each time period (i.e., at 1999, 2002 or 2005). Definitions of the variables are in Appendix D.3. Standard errors are robust to heteroskedasticity and clustered at the firm level. Cook's distance is used to account for influential observation (except columns I-II, Panel B). * $\mathrm{p}<0.1$; ** $\mathrm{p}<0.05$; *** $\mathrm{p}<0.01$. 


\section{Appendices}

\section{Appendix D.1 Data cleaning}

In order to reduce potential selection bias and measurement errors, to deal with severe outliers, and to provide a better comparison of firms across CEE countries, I proceed with the following data cleaning: ${ }^{32}$

- drop firms with data from consolidated statements to avoid double counting of firms or subsidiaries, and duplicates; keep observations for which financial information is reported for a 12 month period;

- transform all industry codes to ISIC rev. 3.1 to align the WBES and Amadeus, and drop firms that do not report industry codes;

- convert all key financial variables into US dollars using period average exchange rates from the IMF, and deflate to 2000 constant prices using countries' GDP deflators;

- impute the missing values of key variables using linear interpolation by years in order to restore possibly erroneously missing data, and to have more observations:

- drop firms with an average number of employees fewer than three to exclude, for instance, phantom firms created for tax evasion, and drop firms with age less than one;

- drop severe outliers: $1 \%$ and $99 \%$ percentiles in operational revenue over number of employees, total assets over number of employees, operational earning over total assets, and total debt over total assets for each country, 2-digit industry code, and year. If an outlier is at the beginning or at the end of the time span for a firm, then only the first or last observation is dropped. If the outlier is in the middle of the time period, then the whole firm is dropped;

- drop severe outliers: $99 \%$ percentile of the absolute value of relative yearly changes in operational revenue, operational revenue over number of employees, and total assets for each country and 2-digit industry code. If an outlier is at the beginning or at the end of the time span for a firm, then only the first or last observation is dropped. If the outlier is in the middle of the time period, then the whole firm is dropped.

\footnotetext{
${ }^{32}$ Data cleaning follows other research that uses the Amadeus database (e.g. Klapper et al., 2006; Anos-Casero and Udomsaph, 2009).

${ }^{33}$ As a robustness check the analysis is also done using the data without imputation; in either way the results are virtually the same.
} 


\section{Appendix D.2 Data representativeness}

Table reports frequency distributions (in percent) of the number of firms by industry, firm size and country for a subsample of CEE countries which are members of the OECD. In column (I) the data is from the 2005 BEEPS wave; in column (II) the data is from the Amadeus database after excluding severe outliers, 2004; and in column (III) the data is from the OECD.STAN database, 2004. Column (III) is a benchmark, since the data from OECD.STAN cover the whole market for a given subsample. For more accurate comparison, industries with 2-digit ISIC codes 01-14, 16, 37, 40-41, 65-67 and 75-95 are excluded, since they are either not presented in the BEEPS or OECD.STAN. Each number in a column is the relative coverage of the number of firms to the entire sample, numbers in columns for a given category are summed to $100 \%$. For instance, the table shows that micro and small firms are significantly underrepresented in both BEEPS and Amadeus; Poland and Hungary are underrepresented in Amadeus while Czech Republic is overrepresented; wholesale trade industry is overrepresented in Amadeus; and so on.

\begin{tabular}{|c|c|c|c|c|}
\hline & & $\begin{array}{c}(\mathrm{I}) \\
\text { BEEPS }\end{array}$ & $\begin{array}{c}\text { (II) } \\
\text { Amadeus }\end{array}$ & $\begin{array}{c}\text { (III) } \\
\text { OECD.STAN }\end{array}$ \\
\hline \multicolumn{5}{|c|}{ Industry } \\
\hline 15 & Food products and beverages & 6.29 & 3.47 & 1.06 \\
\hline 17 & Textiles & 1.23 & 0.99 & 0.39 \\
\hline 18 & Wearing apparel; fur & 7.56 & 1.16 & 1.21 \\
\hline 19 & Luggage, handbags, footwear & 0.32 & 0.35 & 0.26 \\
\hline 20 & Wood, except furniture & 1.05 & 2.01 & 2.01 \\
\hline 21 & Pulp and paper & 0.21 & 0.58 & 0.13 \\
\hline 22 & Publishing; printing & 1.48 & 1.91 & 1.26 \\
\hline 23 & Coke and petroleum products & 0.07 & 0.07 & 0.00 \\
\hline 24 & Chemicals & 0.63 & 1.04 & 0.16 \\
\hline 25 & Rubber and plastic products & 0.91 & 1.85 & 0.53 \\
\hline 26 & Non-metallic mineral products & 0.98 & 1.34 & 0.72 \\
\hline 27 & Basic metals & 0.63 & 0.5 & 0.06 \\
\hline 28 & Fabricated metal products & 11.07 & 4.13 & 2.63 \\
\hline 29 & Machinery and equipment n.e.c. & 6.26 & 2.54 & 0.99 \\
\hline 30 & Office machinery and computers & 0.04 & 0.2 & 0.06 \\
\hline 31 & Electrical machinery & 0.56 & 1.29 & 0.69 \\
\hline 32 & Communication equipment & 0.04 & 0.57 & 0.28 \\
\hline 33 & Instruments, watches and clocks & 0.32 & 0.77 & 0.64 \\
\hline 34 & Motor vehicles and trailers & 0.39 & 0.5 & 0.08 \\
\hline 35 & Other transport equipment & 0.11 & 0.39 & 0.14 \\
\hline 36 & Furniture; manufacturing n.e.c. & 1.41 & 1.63 & 1.50 \\
\hline 45 & Construction & 10.26 & 10 & 12.94 \\
\hline 50 & Sale and repair of motor vehicles & 2.99 & 4.12 & 4.42 \\
\hline 51 & Wholesale trade & 7.42 & 20.2 & 8.18 \\
\hline 52 & Retail trade & 12.9 & 12.06 & 22.04 \\
\hline 55 & Hotels and restaurants & 5.66 & 2.56 & 4.92 \\
\hline 60 & Land transport & 4.53 & 4.12 & 6.57 \\
\hline 61 & Water transport & 0.11 & 0.08 & 0.03 \\
\hline 62 & Air transport & 0.04 & 0.05 & 0.01 \\
\hline 63 & Supporting transport activities & 2.43 & 2.04 & 1.08 \\
\hline 64 & Post & 0.56 & 0.58 & 0.25 \\
\hline 70 & Real estate activities & 3.16 & 4.41 & 3.18 \\
\hline 71 & Renting of machinery, equipment & 0.88 & 0.55 & 0.44 \\
\hline 72 & Computer and related activities & 1.34 & 2.17 & 2.50 \\
\hline 73 & Research and development & 0.56 & 0.36 & 0.15 \\
\hline 74 & Other business activities & 5.62 & 9.42 & 18.50 \\
\hline \multicolumn{5}{|c|}{ Firm size } \\
\hline $1-9$ & mployees & 45.31 & 37.93 & 93.94 \\
\hline $10-$ & 9 employees & 27.73 & 36.18 & 3.97 \\
\hline $50-$ & 49 employees & 18.31 & 19.89 & 0.94 \\
\hline 250 & - employees & 8.65 & 5.29 & 0.17 \\
\hline \multicolumn{5}{|c|}{ Country } \\
\hline Slo & enia & 6.96 & 6.24 & 2.80 \\
\hline $\mathrm{Hu}$ & gary & 20.53 & 11.15 & 17.79 \\
\hline Pol & & 33.15 & 19.07 & 45.97 \\
\hline $\mathrm{Cze}$ & h Republic & 11.04 & 33.80 & 27.76 \\
\hline Slo & akia & 7.24 & 3.03 & 1.09 \\
\hline Est & nia & 7.21 & 15.78 & 1.12 \\
\hline Lat & & 6.96 & 5.03 & 1.83 \\
\hline Litl & uania & 6.92 & 5.89 & 1.64 \\
\hline
\end{tabular}




\section{Appendix D.3 Definitions of variables}

\begin{tabular}{|c|c|}
\hline Name & Definition and Source \\
\hline Bribery Level & $\begin{array}{l}\text { Bribery level in a local environment. Computed as the average } \\
\text { of frequency to bribe (scaled to }[0,1] \text { variable) within country- } \\
\text { time period-industry-firm size-location size cells. Higher val- } \\
\text { ues stand for higher bribery level. Source: the BEEPS. }\end{array}$ \\
\hline Bribery Dispersion & $\begin{array}{l}\text { (Un)evenness of firms bribing behavior in a local environment. } \\
\text { Computed as the standard deviation of frequency to bribe } \\
\text { (scaled to }[0,1] \text { variable) within country-time period-industry- } \\
\text { firm size-location size cells. Higher values stand for higher } \\
\text { heterogeneity of local environments. Source: the BEEPS. }\end{array}$ \\
\hline Sales Growth & $\begin{array}{l}\text { Change of yearly logarithms of operational revenue (in real } \\
\text { prices), and averaged over three-year time periods. Source: } \\
\text { Amadeus. }\end{array}$ \\
\hline $\begin{array}{l}\text { Labor } \quad \text { Productivity } \\
\text { Growth }\end{array}$ & $\begin{array}{l}\text { Change of yearly logarithms of operational revenue (in real } \\
\text { prices) over number of employees, and averaged over three- } \\
\text { year time periods. Source: Amadeus. }\end{array}$ \\
\hline Total Assets & Logarithm of total assets. Source: Amadeus. \\
\hline Total Assets Squared & Logarithm of total assets squared. Source: Amadeus. \\
\hline Employees & Logarithm of number of employees. Source: Amadeus. \\
\hline Employees Squared & Logarithm of number of employees squared. Source: Amadeus. \\
\hline Profitability & $\begin{array}{l}\text { Profitability is EBIT (earnings before interest and taxes) di- } \\
\text { vided by total assets. Source: Amadeus. }\end{array}$ \\
\hline Market Share & $\begin{array}{l}\text { Market share is the operational revenue of a firm divided by the } \\
\text { sum of operational revenue on a 4-digit industry level. Source: } \\
\text { Amadeus. }\end{array}$ \\
\hline Leverage & $\begin{array}{l}\text { Book leverage ratio is the total debt (current liabilities plus } \\
\text { long term debt) divided by total assets. Source: Amadeus. }\end{array}$ \\
\hline Cash Flow & $\begin{array}{l}\text { Book cash flow is the cash flow divided by total assets. Source: } \\
\text { Amadeus. }\end{array}$ \\
\hline Control of Corruption & $\begin{array}{l}\text { Variable showing the overall level of corruption in a country. } \\
\text { Higher values stand for lower corruption levels. Source: the } \\
\text { Worldwide Governance Indicators, World Bank. }\end{array}$ \\
\hline Rule of Law & $\begin{array}{l}\text { Variable showing the overall quality of institutions in a coun- } \\
\text { try. Original indicator is a scaled to }[0,1] \text { variable. Higher } \\
\text { values stand for weaker institutions. Source: the Worldwide } \\
\text { Governance Indicators, World Bank. }\end{array}$ \\
\hline
\end{tabular}




\section{Working Paper Series}

ISSN 1211-3298

Registration No. (Ministry of Culture): E 19443

Individual researchers, as well as the on-line and printed versions of the CERGE-EI Working Papers (including their dissemination) were supported from institutional support RVO 67985998 from Economics Institute of the ASCR, v. v. i.

Specific research support and/or other grants the researchers/publications benefited from are acknowledged at the beginning of the Paper.

(c) Anna Kochanova, 2012

All rights reserved. No part of this publication may be reproduced, stored in a retrieval system or transmitted in any form or by any means, electronic, mechanical or photocopying, recording, or otherwise without the prior permission of the publisher.

Published by

Charles University in Prague, Center for Economic Research and Graduate Education (CERGE) and

Economics Institute ASCR, v. v. i. (EI)

CERGE-EI, Politických vězňů 7, 11121 Prague 1, tel.: +420 224005 153, Czech Republic.

Printed by CERGE-EI, Prague

Subscription: CERGE-EI homepage: http://www.cerge-ei.cz

Phone: + 420224005153

Email: office@cerge-ei.cz

Web: http://www.cerge-ei.cz

Editor: Michal Kejak

The paper is available online at http://www.cerge-ei.cz/publications/working_papers/.

ISBN 978-80-7343-277-5 (Univerzita Karlova. Centrum pro ekonomický výzkum a doktorské studium)

ISBN 978-80-7344-269-9 (Národohospodářský ústav AV ČR, v. v. i.) 
CERGE-EI

P.O.BOX 882

Politických vězňů 7

11121 Praha 1

Czech Republic http://www.cerge-ei.cz 